\title{
Structural-geomorphological aspects of the Petrinja earthquake M6.2 (Croatia) - preliminary considerations
}

\section{Strukłurno-geomorfološki aspekti petrinjskog potresa M6.2 (Hrvatska) - preliminarna razmatranja}

A strong earthquake of magnitude 6.2 with the epicentre near the town of Petrinja occurred on December $29^{\text {th }}, 2020$ in the fault zone of the right strike-slip Pokupsko Fault in Croatia. The aim of this study was to determine if there are geomorphological indicators of active tectonics in this area. General morphometric methods based on a digital elevation model with a resolution of $10 \mathrm{~m}$ were used. Geomorphological indicators of active tectonics were also determined based on topographic maps and hillshade relief. All the collected data were used to reconstruct the traces of the main morpholineaments on the surface and to determine the main morphostructures. It was found that the central part of the studied area, Hrastovička Gora, has morphological features possibly corresponding to a pop-up structure (positive flower) and that it consists of two separate morphostructures. They are separated from each other by an east-west oriented morpholineament, which is a possible segment of the Pokupsko Fault. Comparison of the collected results with the data on the location of the epicentres of the Petrinja series earthquakes of magnitude 4.0 and higher, which occurred in the period from December $28^{\text {th }}, 2020$ to March $3^{\text {rd }}$, 2021, indicates the possibility that these earthquakes were related to this restraining bending zone of the right horizontal Pokupsko Fault, which should be studied in more detail in the future.

Key words: structural geomorphology, morpholineaments, earthquake, active tectonics, digital elevation model, Petrinja, Croatia
Jak potres magnitude $6.2 \mathrm{~s}$ epicentrom kod Petrinje dogodio se 29. 12. 2020. u rasjednoj zoni desnog Pokupskog rasjeda u Hrvatskoj. Cilj ovog rada bilo je utvrditi postoje li geomorfološki pokazatelji aktivne tektonike na ovom području. Korištene su metode opće morfometrije na temelju digitalnog modela reljefa rezolucije $10 \mathrm{~m}$. Također, na podlogama topografskih karata i sjenčanog reljefa detektirani su geomorfološki indikatori aktivne tektonike. Svi prikupljeni podaci poslužili su za rekonstrukciju tragova glavnih morfolineamenata na površini te za izdvajanje glavnih morfostruktura. Zaključeno je da središnji dio istraživanog prostora, Hrastovička gora, ima morfološke značajke koje moguće odgovaraju pozitivnoj cvjetnoj ili pop-up strukturi te da se sastoji od dviju izdvojenih morfostruktura. One su međusobno odvojene morfolineamentom pružanja istok-zapad koji je moguće segment Pokupskog rasjeda. Usporedba prikupljenih rezultata s podacima o lokacijama epicentara potresa petrinjske serije magnitude 4.0 i više koji su se dogodili u razdoblju od 28.12. 2020. do 3.3.2021., ukazala je na mogućnost da su ovi potresi povezani uz taj transpersijski segment desnog Pokupskog rasjeda, što je potrebno detaljnije istražiti.

Ključne riječi: strukturna geomorfologija, morfolineamenti, potres, aktivna tektonika, digitalni model reljefa, Petrinja, Hrvatska 


\section{Introduction}

The area of northern Croatia was struck by a strong earthquake of magnitude 6.2 on December $29^{\text {th }}, 2020$ with the epicentre near Petrinja. This main earthquake was preceded by several earthquakes $\mathrm{du}-$ ring the previous day, the strongest of which were magnitudes of 5.0, 4.7 and 4.1. The main earthquake was followed by a series of aftershocks, the strongest of which was magnitude 5.0, which occurred on January $6^{\text {th }}, 2021$ (URL 1).

The Pokupsko and Banovina areas have long been known for their seismic activity (Herak et al., 2009) and strong earthquakes have been documented in this seismogenic zone in the past. A notable example is the estimated 5.8 magnitude quake from 1909 with the epicentre near Pokupsko (Herak and Herak, 2010), and an earthquake of magnitude 6.4 in 1969 with the epicentre near Banja Luka (Ustaszewski et al., 2014). Immediately after the main shock of the 2020 Petrinja earthquake, numerous experts, especially seismologists, pointed out that this earthquake zone is located in the northwest-southeast Petrinja seismogenic zone, which is known and recorded in the European database of seismogenic faults under the code name HRSC027 (Share, 2021). It is a sub-vertical right strike-slip fault that runs in an NW-SE orientation and is commonly referred to as the Pokupsko Fault in literature (see Herak and Herak, 2010; Đapo et al. 2020). The fault runs parallel to the Sava Fault (one of the main faults in northwestern Croatia), which, according to Prelogović et al. (1998) and Herak and Herak (2010), also has a pronounced right horizontal component of displacement. A preliminary report on the causes of the earthquakes was published by Vukovski (2021), who showed a geological map outlining the fault near Petrinja as it runs along the northeastern slope of Hrastovička Gora, which was initially assumed to be the cause of the main earthquake and its aftershocks. Subsequently, in a press release, Korbar (2021) proposed an interpretation that the Petrinja earthquake was caused by a system of two strike-slip faults perpendicular to each other. In addition to the line of the Pokupsko Fault, which, according to the author, extends along the northeastern edge of Hrastovička Gora, the line of the Petrinja sinistral strike-slip fault was established, extending northeast-southwest (Korbar, 2021). Based

\section{Uvod}

Područje sjeverne Hrvatske 29. prosinca 2020. pogodio je jak potres magnitude $6.2 \mathrm{~s}$ epicentrom kod Petrinje. Ovom je glavnom udaru tijekom prethodnoga dana prethodilo nekoliko potresa od kojih su najjači bili magnitude 5.0, 4.7 i 4.1. Nakon glavnoga potresa uslijedio je niz naknadnih potresa od kojih je trenutno najjači onaj magnitude 5.0 koji se dogodio 6. siječnja 2021. (Seizmološka služba, 2021a).

Područje Pokuplja i Banovine već je odavno poznato po svojoj seizmičkoj aktivnosti (Herak i dr., 2009). U toj seizmogenoj zoni već su se događali jači potresi u prošlosti. Poznat je onaj procijenjene magnitude 5.8 iz 1909. s epicentrom kod Pokupskog (Herak i Herak, 2010), a jugoistočno od ove seizmogene zone poznat je i potres magnitude $6.4 \mathrm{iz} 1969$. s epicentrom kod Banje Luke (Ustaszewski i dr., 2014). Odmah po glavnom udaru oglasili su se brojni stručnjaci, prvenstveno seizmolozi koji su naglasili da se ova potresna zona nalazi u Petrinjskoj seizmogenoj zoni pružanja sjeverozapad-jugoistok koja je od ranije poznata te je zabilježena i u Europskoj bazi seizmogenih rasjeda pod kodnim imenom HRSC027 (Share, 2021). Radi se o subvertikalnom rasjedu s desnim pomakom i pružanjem SZ-JI koji se u literaturi uglavnom spominje kao Pokupski rasjed (npr. Herak i Herak, 2010; Đapo i dr. 2020). Taj se rasjed pruža paralelno sa Savskim rasjedom, jednim od glavnih rasjeda sjeverozapadne Hrvatske koji prema Prelogović i dr. (1998) i Herak i Herak (2010) također ima izraženu horizontalnu, desnu komponentu pomaka. O uzrocima potresa preliminarno izvješće objavio je Vukovski (2021), u kojem je prikazana geološka karta s ucrtanim tragom rasjeda kod Petrinje koji prolazi sjeveroistočnim obronkom Hrastovičke gore i za koji se preliminarno pretpostavilo da je uzročnik glavnog i niza slabijih potresa. Nakon toga u priopćenju za javnost Korbar (2021) predlaže interpretaciju prema kojoj je petrinjski potres uzrokovan sustavom dvaju međusobno okomitih rasjeda s horizontalnim pomacima. Uz trag Pokupskog rasjeda koji se po autoru pruža uz sjeveroistočni rub Hrastovičke gore dodan je i trag Petrinjskog rasjeda pruža- 
on processing observations from the Sentinel-1 satellite mission (pre-earthquake and post-earthquake observations), data on spatial surface displacements resulting from the main earthquake have been published (Faculty of Geodesy, 2020). Preliminary information on the structural-geomorphological features of this area with a map of the main morpholineaments has been published by Bočić (2021). Mihalić Arbanas et al. (2021), Terzić et al. (2021), and Tomljenović et al. (2021) documented the occurrence of cosmic surface deformations and engineering, geological, and hydrogeological phenomena/problems caused by these earthquakes. On the website of Seismological Service of the Department of Geophysics, Faculty of Sciences, University of Zagreb, an overview of preliminary results of the series of Petrinja earthquakes in the first month following the main earthquake is available, among other relevant data and research (Seismological Survey, 2021c). Markušić et al. (2021) published detailed preliminary results of macroseismic, geological, geodetic, and civil engineering investigations. It is assumed that this earthquake was the result of the activation of two main horizontal faults (the NW-SE extension of the dextral Pokupsko Fault, and the NE-SW extension of the sinistral Petrinja Fault), due to north-south compression. They also stated that the epicentre of the main earthquake was located on the Petrinja Fault Line. Tondi et al. (2021) also wrote about the causes of the Petrinja earthquake. They concluded that there was Y-shear of the NW-SE strike with a right-lateral displacement (they called this fault "Župić") and X-shear of the NW-SE orientation along the so-called Kupa Fault with a left-lateral displacement. They believe that these cosmically conjugate faults were activated during the Petrinja earthquake within the principal displacement zone of the pre-existing active Petrinja Fault Zone, as a result of the current tectonic stress associated with the ongoing movement of the Adriatic Plate in relation to the Eurasian Plate.

The basic geomorphological features of the wider study area were presented by Hećimović and Prelogovic (1987) as part of the explanatory book of the Basic Geological Map 1: 100,000 for the Sisak sheet (Pikija, 1987b). Within the framework of this work, they also elaborated the Hrastovica morphostructure, with which this paper is largely concerned. nja sjeveroistok-jugozapad i s lijevim pomakom (Korbar, 2021). Na temelju obrade opažanja Sentinel-1 satelitske misije (opažanje prije i poslije potresa) objavljeni su podaci o prostornim, površinskim pomacima koji su se dogodili uslijed glavnog potresa (Geodetski fakultet, 2020). Preliminarne informacije o strukturno-geomorfološkim obilježjima ovog područja s kartom glavnih morfolineamenata objavljuje Bočić (2021). O pojavama koseizmičkih površinskih deformacija te inženjerskogeološkim i hidrogeološkim pojavama i problemima uzrokovanim ovim potresima izvijestili su Mihalić Arbanas i dr. (2021), Terzić i dr. (2021) i Tomljenović i dr. (2021). Na mrežnim stranicama Seizmološke službe pri Geofizičkom odsjeku PMF-a Sveučilišta u Zagrebu, uz mnoge analize i relevantne informacije, objavljen je i pregled preliminarnih rezultata istraživanja serije petrinjskih potresa u prvih mjesec dana od glavnog potresa (Seizmološka služba, 2021c). Markušić i dr. (2021) objavljuju detaljne preliminarne rezultate makroseizmičkih, geoloških, geodetskih i građevinskih istraživanja. Smatraju da je taj potres bio rezultat aktiviranja dvaju glavnih horizontalnih rasjeda (desnog Pokupskog, pružanja SZ-JI i lijevog Petrinjskog, pružanja SI-JZ), a uslijed kompresije po pravcu sjever-jug. Također navode da je epicentar glavnog potresa na rasjednoj liniji Petrinjskog rasjeda. O uzrocima petrinjskog potresa pišu Tondi i dr. (2021). Zaključuju da je došlo do Y-smicanja orijentacije SZ-JI s desnim pomakom (ovaj rasjed nazivaju Župić) te X-smicanja orijentacije SZ-JI duž tzv. Kupskog rasjeda s lijevim pomakom. Smatraju da su ovi koseizmički konjugirani rasjedi tijekom potresa u Petrinji nastali unutar zone glavnog pomaka već postojeće aktivne Petrinjske rasjedne zone, a kao posljedica trenutnog tektonskog stresa povezanog s kretanjem Jadranske mikroploče u odnosu na Euroazijsku ploču.

Osnovne geomorfološke značajke šireg istraživanog područja prikazali su Hećimović i Prelogović (1987) u okviru Tumača osnovne geološke karte 1:100.000 za list Sisak (Pikija, 1987b). U okviru tog tumača izdvajaju i Hrastovičku morfostrukturu kojom se u najvećoj mjeri bavi i ovaj rad.
Structuralgeomorphological aspects of the

Petrinja earthquake

M6.2 (Croatia) - preliminary considerations

Strukturnogeomorfološki aspekti petrinjskog potresa M6.2 (Hrvatska) preliminarna razmatranja 
The aim of this work is to use geomorphological methods to preliminarily determine how much active tectonics have influenced the formation of the relief of this area, i.e. whether traces of active tectonics and related geomorphological structures visible on the surface can be found in the relief of this area. Also, an additional goal was to compare the spatial distribution of the epicentres of the strongest earthquakes $\left(\mathrm{M}_{\mathrm{L}}>=\right.$ 4.0) from this series and the geomorphological traces of active tectonics.

\section{Study area}

The epicentre of the main earthquake was located in the area of northwestern Croatia, about $6.5 \mathrm{~km}$ southwest of the town of Petrinja, on the southwestern slopes of Hrastovička Gora (Fig. 1A). According to the geomorphological regionalization of the Republic of Croatia (Bognar, 1999), the wider area of the epicentre belongs to the mesogeomorphological region 1.3.6. Zrinska Gora and Trgouska Gora massifs with the Banija and Petrinja-Sunja bills, and in the immediate vicinity of region 1.3.5 Sava lowland in the northeast and region 1.3.6 Vukomericke Gorice with the Crna Mlaka depression in the northwest. The central geomorphological-physionomic unit of the study area is Hrastovička Gora, which extends along a generally Dinaric orientation (Fig. 1B). In the southwest we find the northern slopes of Zrinska Gora and $\mathrm{Ba}^{-}$ nijsko Pobrđe, and the Glina River Valley. In the northwestern continuation of Hrastovička Gora, the less pronounced Vukomeričke Gorice continue in relief, separated by the Kupa River Valley. The northeastern part of the study area consists of the lowlands of the Sava River and associated terraces.

Geotectonically, this area belongs to the Supradinaric Geotectonic Belt, i.e. the Inner Dinarides (Herak, 1991). Within the southwestern part of the Pannonian Basin, Prelogović et al. (1998) defined three structural units. The studied area belongs to the Southern Marginal Fault structural unit, which is separated from the Central Fault structural unit by the right horizontal Sava Fault. According to the data from Basic Geological Map 1: 100 000, for the Sisak and Bosanski Novi sheets (Pikija, 1987a; 1987b; Šikić, 1990; 2014), Neogene
Cilj je ovog rada geomorfološkim metodama preliminarno utvrditi koliko je aktivna tektonika utjecala na oblikovanje reljefa ovog područja, odnosno mogu li se u reljefu navedenoga područja pronaći tragovi aktivne tektonike i s njom povezane geomorfološke strukture vidljive na površini. Dodatni je cilj usporediti prostorni raspored epicentara najjačih potresa $\left(\mathrm{M}_{\mathrm{L}}>=4.0\right)$ iz ove serije i geomorfoloških tragova aktivne tektonike.

\section{Istraživano područje}

Epicentar glavnog potresa bio je na području sjeverozapadne Hrvatske, oko 6,5 km jugozapadno od grada Petrinje, na jugozapadnim obroncima Hrastovičke gore (sl. 1A). Prema geomorfološkoj regionalizaciji Republike Hrvatske (Bognar, 1999) šire područje epicentra pripada mezogeomorfološkoj regiji 1.3.6. Gorski masivi Zrinske i Trgovske gore s Banijskim i Petrinjsko-sunjskim pobrđem, a u neposrednoj je blizini regije 1.3.5. Nizina Save na sjeveroistoku te regije 1.3.6. Vukomericke gorice sa zavalom Crne Mlake na sjeverozapadu. Središnja geomorfološko-fizionomska cjelina istraživanog područja jest Hrastovička gora s približno dinarskim pružanjem (sl. 1B). Jugozapadno se nalaze sjeverni obronci Zrinske gore i Banijsko pobrđe s dolinom rijeke Gline. U sjeverozapadnom nastavku Hrastovičke gore nastavljaju se reljefno slabije izražene $\mathrm{Vu}$ komeričke gorice, a međusobno ih odvaja dolina rijeke Kupe. Sjeveroistočni dio istraživanog područja čini nizina rijeke Save s pripadajućim terasama.

U geotektonskom smislu ovo područje pripada geotektonskom pojasu Supradinarik, tj. Unutarnjim Dinaridima (Herak, 1991). U okviru jugozapadnog dijela Panonskog bazena Prelogović i dr. (1998) definirali su tri strukturne jedinice. Istraživano područje pripada strukturnoj jedinici Južni marginalni dio koja je desnim horizontalnim Savskim rasjedom odvojena od strukturne jedinice Središnji dio. Prema podacima Osnovne geološke karte 1:100 000 listovi Sisak i Bosanski Novi (Pikija, 1987a; 1987b; Šikić, 1990; 2014) u geološkoj građi istraživanog područja prevlada- 
and Quaternary deposits dominate the geological structure of the studied area. The oldest rocks of the studied area are Cretaceous deposits (in which limestones prevail) and spills. They occur only locally in the part of the northwestern foothills of Hrastovička Gora. They are followed by Paleocene (Pc) and Paleocene-Eocene (Pc, E) clastic and carbonate deposits, which occur in the most deeply-incised valleys. Most of Hrastovička Gora is covered by Middle and Upper Miocene deposits $\left(\mathrm{M}_{2}{ }^{2},{ }_{1} \mathrm{M}_{3}{ }^{1}\right.$, $\left.{ }^{2} \mathrm{M}_{3}^{1,2}\right)$, in which limestones and marls prevail, but medium and fine-grained clastic deposits are also present. In the transgressive sequence there are Pliocene $\left(\mathrm{Pl}_{1}{ }_{1}, \mathrm{Pl}_{1}{ }^{2}, \mathrm{Pl}_{2,3}\right)$ and Pliocene-Quaternary $(\mathrm{Pl}, \mathrm{Q})$ deposits of marl and clastic sediments, which form most of the area northeast and southwest of Hrastovička Gora and Vukomeričke Gorice in the northwest. Alluvial, marshy, proluvial and other Holocene deposits are present in river valleys and their margins.

This area is located between the Sava Fault in the north and the Southern Marginal Fault of the Pannonian Basin in the south, and according to the seismic zoning of Croatia, and it is part of seismogenic zone 12: Kupa Valley (Markušić and Herak, 1998). The most significant fault of this zone is the Pokupsko Fault (Fig. 1A; Herak and Herak, 2010). vaju naslage neogena i kvartara. Najstarije stijene istraživanog područja jesu kredne naslage u kojima prevladavaju vapnenci te kredni spiliti. Pojavljuju se samo lokalno na dijelu sjeverozapadnog podnožja Hrastovičke gore. Slijede paleocenske (Pc) i paleocensko-eocenske (Pc, E) klastične i krabonatne naslage koje su prisutne $\mathrm{u}$ najdublje usječenim dolinama. Najveći dio Hrastovičke gore prekrivaju srednje i gornjomiocenske naslage $\left(\mathrm{M}_{2}{ }^{2},{ }_{1} \mathrm{M}_{3}{ }^{1},{ }^{2} \mathrm{M}_{3}{ }^{1,2}\right)$ u kojima prevladavaju vapnenci i lapori, ali su prisutne srednje i sitnozrnate klastične naslage. $U$ transgresivnom slijedu nalaze se pliocenske $\left(\mathrm{Pl}_{1}{ }^{1}, \mathrm{Pl}_{1}{ }^{2}, \mathrm{Pl}_{2,3}\right)$ i pliocensko-kvartarne $(\mathrm{Pl}, \mathrm{Q})$ naslage lapora i nevezanih klastičnih sedimenata koje izgrađuju veći dio područja sjeveroistočno i jugozapadno od Hrastovičke gore te Vukomeričke gorice na sjeverozapadu. U dolinama rijeka i njihovim rubovima prisutne su aluvijale, barske, proluvijalne i druge holocenske naslage.

Ovo se područje nalazi između Savskog rasjeda na sjeveru te Južnog marginalnog rasjeda Panonskog bazena na jugu te je prema seizmičkom zoniranju Hrvatske dio seizmogene zone 12: Dolina Kupe (Markušić i Herak, 1998). Najznačajniji rasjed ove zone jest Pokupski rasjed (sl. 1A; Herak i Herak, 2010).

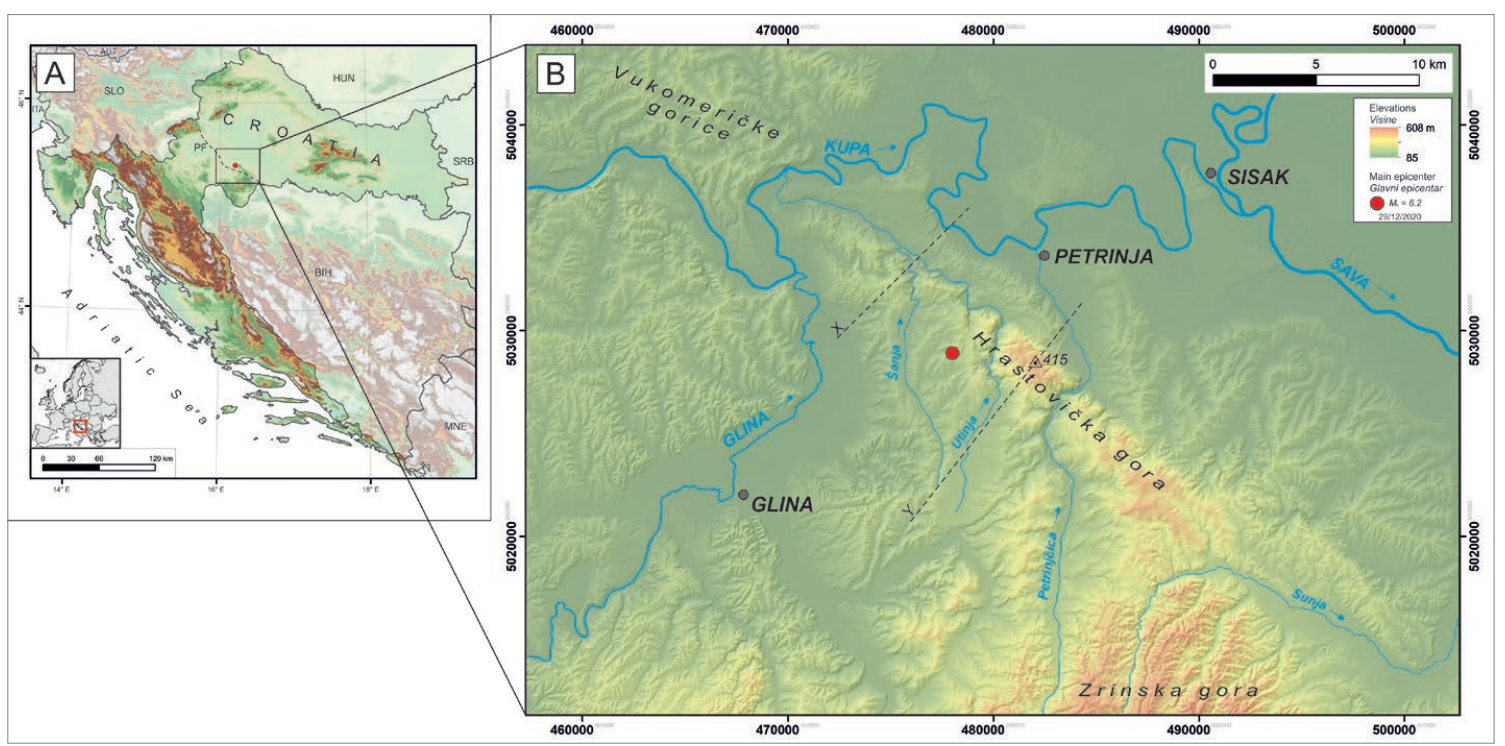

Fig. 1 Location and extent of the study area. $X$ and $Y$ in Figure $1 B$ show the position of the topographic profiles shown in Figure 6 SI. 1. Položaj i obuhvat istraživanog područja. X i Y na slici IB prikazuju položaj topografskih profila prikazanih na slici 6 


\section{Methods}

The preliminarystructural-geomorphologicalanalysis aimed to identify geomorphological indicators of active tectonics. The analysis was based on the interpretation of the digital elevation model (DEM), morphometric maps, topographic maps 1:25,000 (Croatian Geodetic Administry, 2021), and in correlation with the data presented on the Basic Geological Map 1:100,000 sheets Sisak and its explanatory booklet (Pikija, 1987a; 1987b). The analysis used a DEM with a resolution of $10 \times 10 \mathrm{~m}$, made on the basis of altitude data from the State Geodetic Administration. Landscape visualisation was done using a coloured elevation scale, a hillshade model, and a $3 \mathrm{D}$ view. The hillshade model was created by simulating illumination at an angle of $45^{\circ}$ from four directions $\left(45^{\circ}, 135^{\circ}, 225^{\circ}\right.$, and $\left.315^{\circ}\right)$.

The first step was to create general morphometric maps. Methods were used to analyse elevation, slope inclination, relative relief, and slope aspect. The ArcGIS 10 software package with the Spatial and 3D Analyst extensions was used for all morphometric analyses. Slope was calculated using the Slope tool, using the $3 \times 3$ square method, i.e. unit DEM cells. Relative relief was calculated using the Focal Statistics function as the vertical difference of the highest and lowest points within a circle with a radius of $564 \mathrm{~m}$, corresponding to an area of $1 \mathrm{~km}^{2}$. The aspect of the slopes implies their orientation with respect to the sides of the world, i.e. they are categorized into groups of $45^{\circ}$. In the preliminary morphometric analysis, the focus was on the interpretation of the morphometric maps, i.e. on the spatial distribution and the relationship of categories of the analysed parameters. A detailed statistical analysis was not performed at this stage. The morphometric maps were primarily used to detect morpholineaments and morphostructures. In addition to the morphometric maps, two transverse topographic profiles were created based on DEM.

The second step was to detect and map geomorphological indicators of active tectonics. For this purpose, topographic maps, previously created morphometric maps, and hillshade were used as a basis. All recognised shapes such as watergaps, steep slopes, elbow-shaped valley bends, etc. were recorded. Based on the collected data, the third step was carried out, in which the obtained results were interpreted, i.e.

\section{Metode rada}

Preliminarna strukturno-geomorfološka analiza bila je usmjerena na prepoznavanje geomorfoloških indikatora aktivne tektonike. Analiza je izvršena na temelju interpretacije digitalnog modela reljefa (DMR), morfometrijskih karata, topografskih karata 1:25 000 (Državna geodetska uprava, 2021), a u korelaciji s podacima prikazanim na Osnovnoj geološkoj karti 1:100 000 lista Sisak i tumača te karte (Pikija, 1987a; 1987b). U analizi je korišten DMR rezolucije $10 \times 10 \mathrm{~m}$, izrađen na temelju visinskih podataka Državne geodetske uprave. Izrađeni su prikazi reljefa u visinskoj skali, sjenčanom modelu i 3D izgledu. Sjenčani model izrađen je simulacijom osvjetljenja pod kutom $45^{\circ}$ iz četiriju smjerova $\left(45^{\circ}, 135^{\circ}, 225^{\circ}\right.$ i $\left.315^{\circ}\right)$.

Prvi korak bila je izrada općih morfometrijskih karata. Korištene su metode analize visina, nagiba, vertikalne raščlanjenost reljefa te ekspozicije i zakrivljenosti padina. $\mathrm{Za}$ sve morfometrijske analize korišten je programski paket ArcGIS $10 \mathrm{~s}$ ekstenzijama Spatial i 3D Analyst. Nagib padina računan je alatom Slope, korištenjem metode $3 \mathrm{x}$ 3 kvadrata, tj. jediničnih ćelija DEM-a. Vertikalna raščlanjenost računana je funkcijom Focal Statistics kao visinska razlika najviše i najniže točke u krugu radijusa $564 \mathrm{~m}$, što odgovara površini od $1 \mathrm{~km}^{2}$. Ekspozicija padina podrazumijeva njihovu orijentaciju u odnosu na glavne i sporedne strane svijeta, tj. kategorizirana je u grupe od po $45^{\circ}$. U ovoj preliminarnoj morfometrijskoj analizi naglasak je bio na interpretaciji morfometrijskih karata, tj. prostornom rasporedu i odnosu pojedinih kategorija analiziranih parametara. Detaljna statistička analiza u ovoj fazi nije izvršena. Morfometrijske karte u prvom su redu poslužile za detektiranje morfolineamenata i morfostruktura. Uz morfometrijske karte na temelju DEM-a izrađena su i dva poprečna topografska profila.

Drugi korak bilo je detektiranje i kartiranje geomorfoloških indikatora aktivne tektonike. $\mathrm{Za}$ tu svrhu korištene su topografske karte, prethodno izrađene morfometrijske karte te prikazi sjenčanog reljefa. Ucrtani su svi prepoznati oblici poput probojnica, pregiba u reljefu, laktastih skretanja i sl. $\mathrm{Na}$ temelju prikupljenih podataka načinjen je treći ko- 
the main morphostructures were identified-relatively homogeneous relief units, primarily of tectonic origin (Gerasimov and Mescherikov, 1968). In this step, the routes of the morpholineaments were defined, possibly corresponding to the traces of the assumed faults, as well as some previously identified lines.

The final step was a comparison of the obtained structural geomorphological data with the spatial distribution of earthquake epicentres. Unfortunately, we were not able to obtain accurate data on the position and depth of earthquake epicentres from the Croatian Seismological Service. Therefore, the position data were obtained from the archive of the official earthquake reports of the Croatian Seismological Service (Seismological Survey, 2021b), which are regularly published on their official website. Only the position data of earthquakes of magnitude 4.0 and higher, of which there were 15 (in the period from December $28^{\text {th }}, 2020$ to March $3^{\text {rd }}, 2021$ ), were analysed. For four earthquakes, the coordinates of the epicentre were published, while for the other earthquakes the location of the epicentre was taken from cartographic representations of the reporting archive. These representations were of sufficient quality to provide location data with an estimated error of no more than 1000 $\mathrm{m}$. These are the only publicly available data, but they were published immediately after the earthquake and no corrected data were published later.

For the spatial analysis of these epicentres, the function Directional Distribution (Standard Deviational Ellipse) was used, which, using the following parameters: centre; long and short axis; orientation of the ellipse; etc., shows a tendency to group spatial data by direction (ArcGIS, 2021). The objective was to determine the extent to which the epicentres of the strongest earthquakes related to the lines of the observed morpholineaments. The numerical eccentricity of the obtained ellipse was calculated as an indicator of the extended grouping of said epicentres. The higher this value is, i.e. closer to 1 , the more elongated the ellipse is. The Directional Distribution function has been previously used in geostatistical analyses of the spatial distribution of earthquake epicentres in different areas (e.g., Al Dogom, 2018; Djenaliev, 2018; Aslam, 2020). All cartographic contributions in this paper are presented in the Croatian reference coordinate system HTRS96/TM (Lapaine and Tutić, 2007). rak u okviru kojeg su interpretirani postignuti rezultati tj., načinjeno je prepoznavanje glavnih morfostruktura - relativno homogenih reljefnih cjelina prvenstveno tektonskog postanka (Gerasimov i Mescherikov, 1968). U ovom koraku definirane su trase morfolineamenata koji moguće odgovaraju tragovima pretpostavljenih rasjeda, kao i nekih već ranije utvrđenih.

Kao posljednji korak u ovom radu izvršena je usporedba dobivenih strukturno-geomorfoloških podataka s prostornim rasporedom epicentra potresa. Nažalost, točne podatke o položaju i dubini epicentra potresa nismo uspjeli dobiti od Seizmološke službe RH. Stoga su podaci o položaju preuzimani iz arhive službenih izvješća o potresima Seizmološke službe RH (2021b) koja su redovito objavljivana na njihovim službenim stranicama. Analizirani su podaci o položaju samo potresa magnitude od 4.0 naviše kojih je u razdoblju od 28. 12.2020. do 3. 3. 2021. bilo 15 . Za četiri potresa objavljene su koordinate epicentra, dok su za ostale potrese lokacije o epicentru preuzete s kartografskih prikaza iz arhive obavijesti. Takvi prikazi bili su dovoljne kvalitete da se podaci o lokaciji preuzmu s procijenjenom pogreškom ne većom od $1000 \mathrm{~m}$. To su jedini podaci koji su javno dostupni, ali su objavljivani neposredno nakon potresa i kasnije nisu objavljivani korigirani podaci.

Za prostornu analizu navedenih epicentara korištena je funkcija Directional Distribution (Standard Deviational Ellipse) koja s pomoću parametara: središte, duga i kratka os i orijentacija elipse, među ostalim pokazuje tendenciju grupiranja prostornih podataka prema smjeru (ArcGIS, 2021). Svrha je bila utvrditi u kojoj se mjeri epicentri najjačih potresa vežu za tragove uočenih morfolineamenata. Kao pokazatelj izdužena grupiranja navedenih epicentara izračunan je numerički ekscentricitet dobivene elipse. Što je ta vrijednost veća, tj. bliža 1, elipsa je izduljenija. Funkcija Directional Distribution dosad je već korištena u geostatističkoj analizi prostornog rasporeda epicentara potresa u različitim područjima (npr. Al Dogom, 2018; Djenaliev, 2018; Aslam, 2020). Svi kartografski prilozi u ovom radu prikazani su u hrvatskom referentnom koordinatnom sustavu HTRS96/TM (Lapaine i Tutić, 2007).
Structuralgeomorphological aspects of the

Petrinja earthquake

M6.2 (Croatia) - preliminary considerations

Strukturnogeomorfološki aspekti petrinjskog potresa M6.2 (Hrvatska) preliminarna razmatranja 
HRVATSKI

GEOGRAFSKI

GLASNIK

83/1, 5-24 (2021.)

\section{Results}

\section{Morphometric characteristics of the relief}

The elevation map (Fig. 2) clearly shows two distinct parts of the terrain. One is lower and belongs to the Sava Valley. It is located northeast of Hrastovička Gora. The lowest elevation on the map is roughly $90 \mathrm{~m}$, along the Sava River. The altitude of Petrinja is roughly $100 \mathrm{~m}$, and this area is located in the northeastern foothills of Hrastovička Gora, which has a maximum altitude of $415 \mathrm{~m}$. Hrastovička Gora extends in a northwest-southeast direction for about $40 \mathrm{~km}$, and the length of its central, highest and most pronounced part is about $15 \mathrm{~km}$. The width of Hrastovička Gora in its central, widest part is not more than $4 \mathrm{~km}$. The southwestern foot of Hrastovička Gora is slightly higher than the northeastern (Petrinja) side. It is fragmented and uneven in height (from about

\section{Rezultati}

\section{Morfometrijski pokazatelij reljefa}

Na karti visina (sl. 2) jasno se mogu uočiti dva različita dijela terena. Jedan je niži koji pripada dolini Save, a nalazi se sjeveroistočno od Hrastovičke gore. Najniža je visina na prikazanoj karti oko 90 m, uz samu rijeku Savu. Nadmorska visina Petrinje iznosi oko $100 \mathrm{~m}$, a to se područje nalazi u sjeveroistočnom podnožju Hrastovičke gore, čija je najveća visina $415 \mathrm{~m}$. Hrastovička gora pruža se pravcem sjeverozapad-jugoistok u duljini od oko $40 \mathrm{~km}$, a duljina njezina središnjeg, najvišeg i reljefno najizraženijeg dijela iznosi oko $15 \mathrm{~km}$. Širina Hrastovičke gore u središnjem, najširem dijelu ne prelazi $4 \mathrm{~km}$. Jugozapadno podnožje Hrastovičke gore nešto je više od sjeveroistočnog, petrinjskog. Znatno je raščlanjenije i neujednačenih visina (od

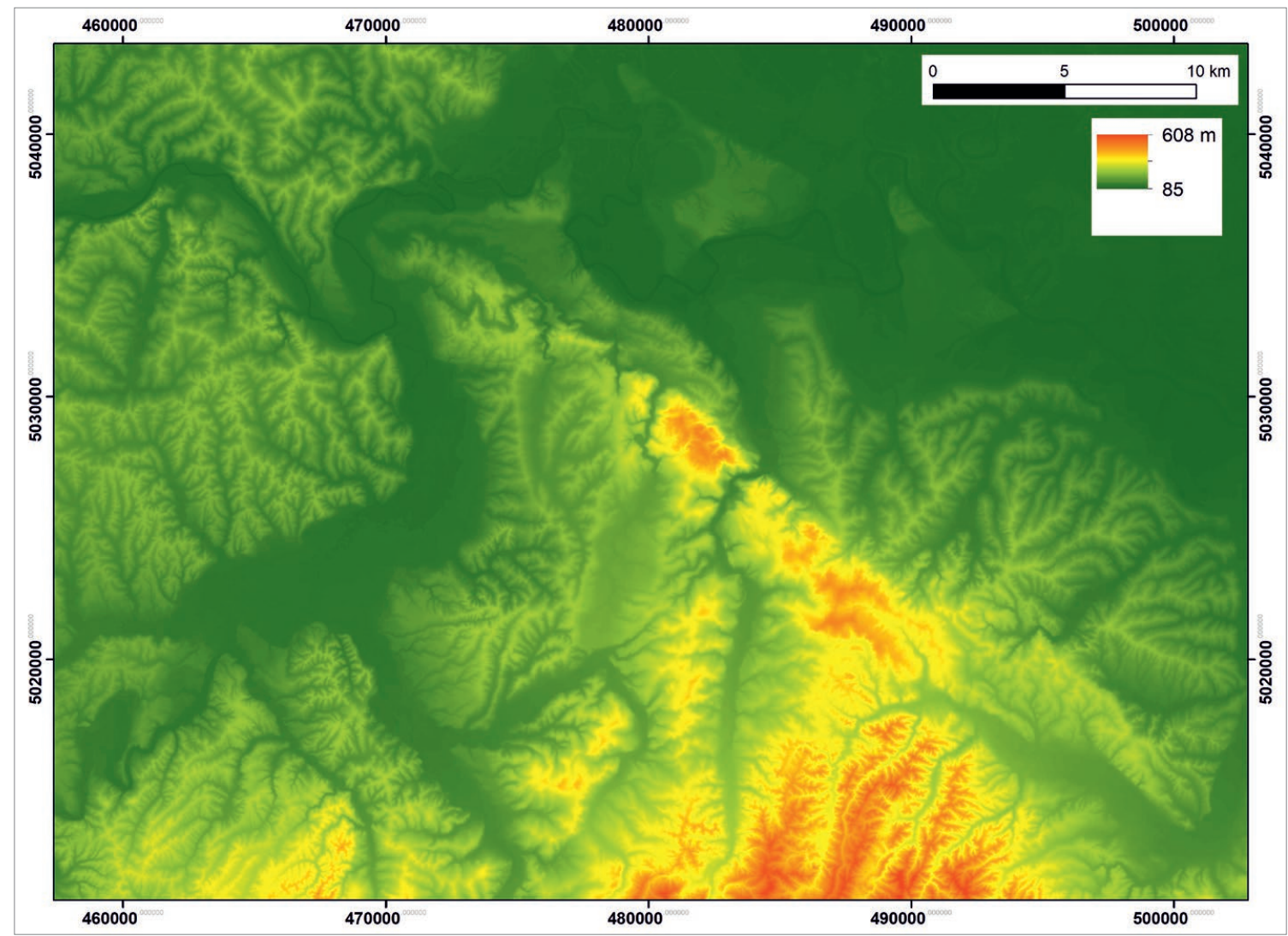

Fig. 2 Elevation map of the Petrinja area (based on DEM with $5 \times 5$ m resolution)

SI. 2. Visinska karta okolice Petrinje (prikaz na temelju DMR-a rezolucije $10 \times 10 \mathrm{~m}$ ) 
$105 \mathrm{~m}$ at the confluence of the Glina River and the Kupa River, to about $310 \mathrm{~m}$ in the area that continues south to Zrinska Gora), but orographically distinct.

The slope map (Fig. 3) shows an elongated zone of steep slopes on the northeastern hillslopes of Hrastovička Gora. In the northern part of Hrastovička Gora, this zone is less pronounced, changes its course in a west-northwest direction, crosses the Kupa Valley, and then continues along the southwestern edge of Vukomeričke Gorice. Here it is much wider, and the steep slopes have different orientations. At the southeastern end of Hrastovicka Gora there are several parallel zones with a Dinaric orientation and steeper slopes. The largest zone in terms of area with the steepest slopes refers to the southern, hypsometrically higher part of the terrain, i.e. mainly to the area of Zrinska Gora. This zone does not have a distinct orientation and is rather related to the erosive effects of streams flowing to the north. oko 105 m na ušću Gline u Kupu do oko 310 m na području koje se nastavlja na Zrinsku goru prema jugu), ali je orografski jasno izraženo.

Karta nagiba padina (s1. 3) ukazuje na jednu izduženu zonu strmih padina na sjeveroistočnim obroncima Hrastovičke gore. U sjevernom dijelu Hrastovičke gore ta je zona slabije izražena, mijenja pružanje prema zapad-sjeverozapadu, prelazi dolinu Kupe te se potom nastavlja dalje uz jugozapadni rub Vukomeričkih gorica. Ovdje je ta zona znatno šira, a strme padine različite su orijentacije. Na jugoistočnom kraju Hrastovičke gore nalazi se nekoliko paralelnih zona dinarske orijentacije sa strmijim padinama. Površinski najveća zona velikih nagiba vezana je za južni, hipsometrijski viši dio terena, tj. uglavnom za područje Zrinske gore. Ova zona nema neku izraženu orijentaciju te je više povezana s erozijskim djelovanjem tokova koji otječu prema sjeveru.

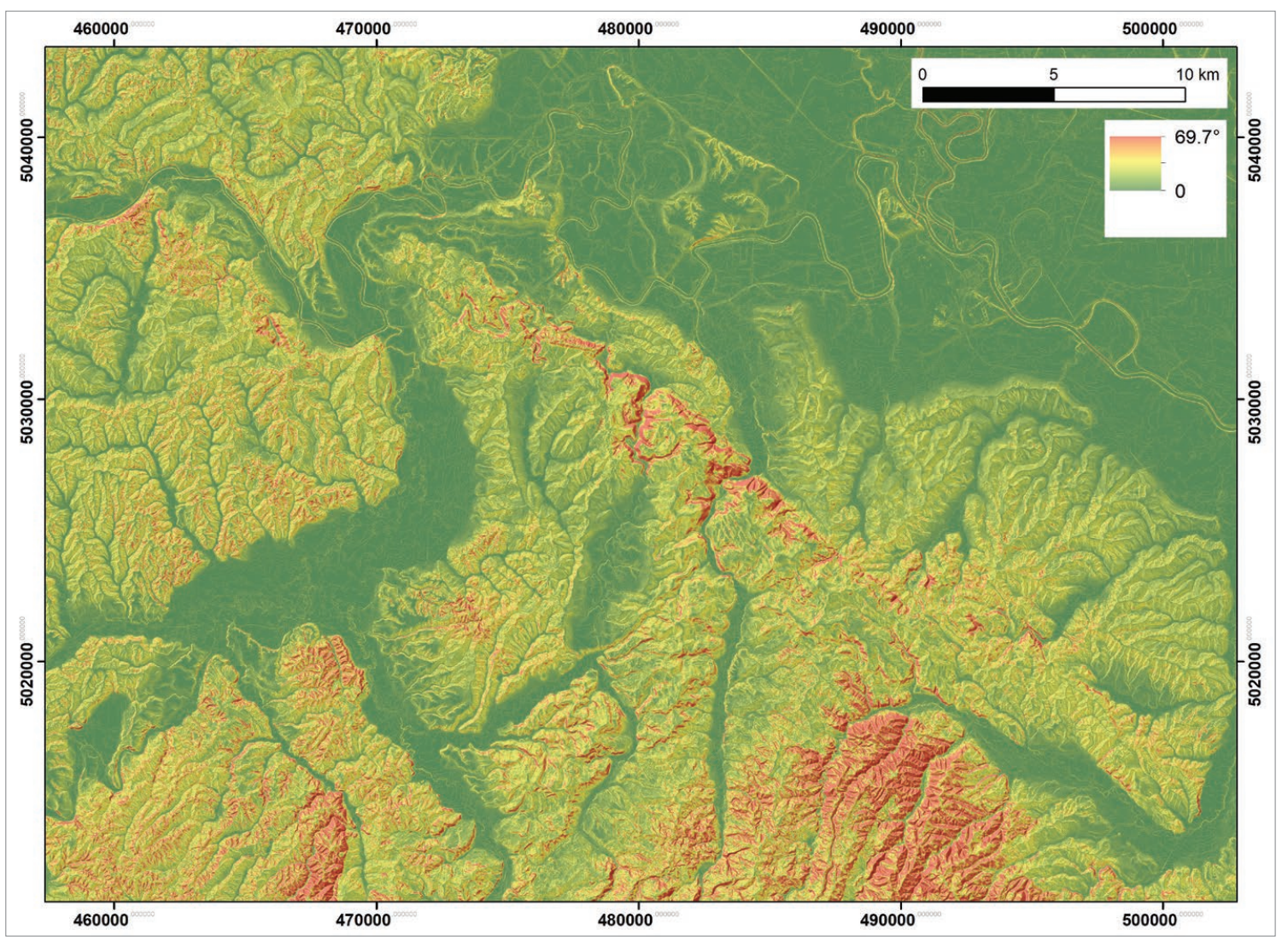

Fig. 3 Slope map of the Petrinja area

SI. 3. Karta nagiba padina okolice Petrinje 
HRVATSKI

GEOGRAFSKI

GLASNIK

83/1, 5-24 (2021.)
Relative relief (Fig. 4) is the difference in elevation between the highest and lowest points per unit area, expressed in $\mathrm{m} / \mathrm{km}^{2}$. It indicates potential erosion and thus possible tectonic activity. The greatest relative relief in this area is related to the hillslopes of Hrastovička Gora on both sides, but is more pronounced on the northeastern side than on the southwestern side. Large height differences along these slopes indicate more intense erosion that developed due to an increase in hydraulic gradient. This may indirectly indicate active tectonics, i.e. possible uplift of Hrastovicka Gora. This zone of increased relative relief continues to the northwest and southeast, but is less pronounced. Increased relative relief, as well as increased slopes, also includes the southern part of this area, mainly related to Zrinska Gora.

The slope aspect (Fig. 5) shows, among others, areas with straight, elongated, uniformly oriented slopes. They mark clearly pronounced morpholineaments, which may be a consequence of active tectonics, i.e. in tecto-
Vertikalna raščlanjenost reljefa (sl. 4) visinska je razlika najviše i najniže točke po jedinici površine izražena u $\mathrm{m} / \mathrm{km}^{2}$. Ukazuje na potencijalnu eroziju, a time posredno i na eventualno moguću tektonsku aktivnost. Najveća vertikalna raščlanjenost na ovom prostoru vezana je za obronke Hrastovičke gore, i to za njezine obje strane, no izraženije za sjeveroistočnu nego za jugozapadnu stranu. Veće visinske razlike duž ovih padina ukazuje na intenzivniju eroziju koja se razvila uslijed povećanja hidrauličkog gradijenta. To posredno može upućivati na aktivnu tektoniku odnosno moguće izdizanje Hrastovičke gore. Ova zona povećane vertikalne raščlanjenosti nastavlja se prema sjeverozapadu i jugoistoku, ali je dalje sve slabije izražena. Povećana vertikalna raščlanjenost te povećani nagibi obuhvaćaju i južni dio ovog područja, uglavnom vezanog za Zrinsku goru.

Ekspozicija padina (sl. 5), među ostalim, ukazuje na područja ravnih, izduženih, jednako orijentiranih padina. One jasno markiraju izražene morfolineamente koji su moguće posljedica aktive tektonike, tj. u tek-

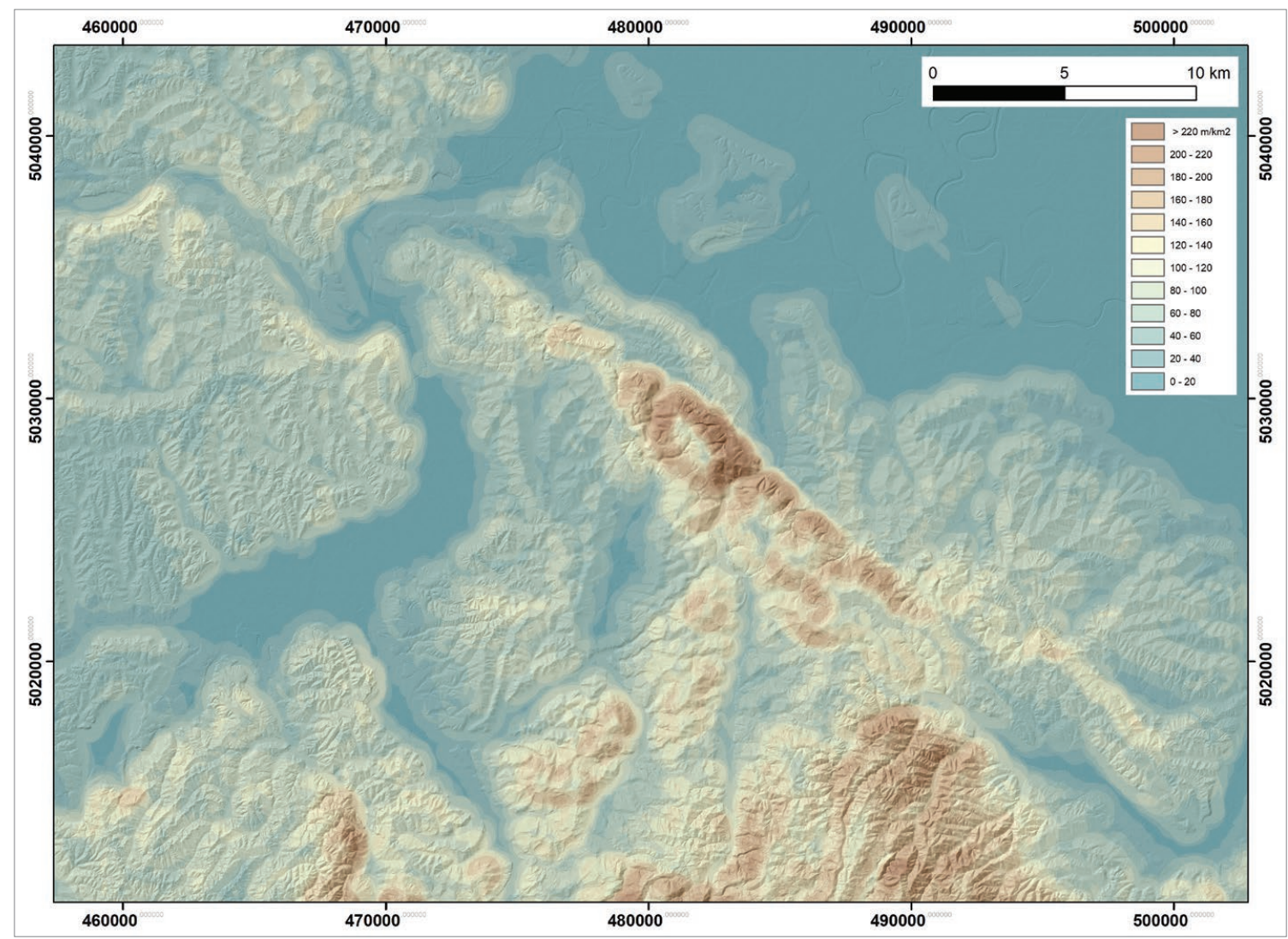

Fig. 4 Map of the relative relief of the Petrinja area

SI. 4. Karta vertikalne raščlanjenosti reljefa okolice Petrinje 
nically active terrain they may indicate surface traces of faults. In the area of Hrastovička Gora, rows of slopes with exposures to the northeast and southwest are clearly visible, indicating the alignment of the main morpholineaments along the prevailing Dinaric orientation (NW-SE). Diagonal morpholineaments with approximate north-south extension are also visible. Orientations indicating their transversal extension (northeast-southwest) are somewhat less pronounced in relief.

Two characteristic transversal topographic profiles were created, perpendicular to the extension of $\mathrm{Hra}^{-}$ stovicka Gora (Fig. 6). The elevated parts of the relief indicate two assumed morphostructures (1 - the Hrastovica morphostructure, 2 - the Križ morphostructure). The stair-like bends in the profile reflect the position of the morpholineaments bounded by the aforementioned morphostructures and possibly represent lines of active faults. tonski aktivnim terenima moguće ukazuju na površinske tragove rasjeda. Na području Hrastovičke gore jasno se uočavaju nizovi padina s ekspozicijama prema sjeveroistoku te prema jugozapadu, što sugerira pružanje glavnih morfolineamenata dinarskim pravcem (cca SZ-JI). Vidljivi su također dijagonalni morfolineamenti približnog pružanja sjever-jug. Nešto su manje u reljefu izražene orijentacije padina koje ukazuju na njihovo poprečno pružanje (sjeveroistok-jugozapad).

Izrađena su dva karakteristična poprečna topografska profila koji se pružaju okomito na pružanje Hrastovičke gore (sl. 6). Izdignuti dijelovi reljefa ukazuju na dvije pretpostavljene morfostrukture (1 - morfostrukturu Hrastovica, 2 - morfostrukturu Križ). Pregibi u reljefu odražavaju položaj morfolineamenata koji su granični navedenim morfostrukturama, a moguće predstavljaju tragove aktivnih rasjeda.

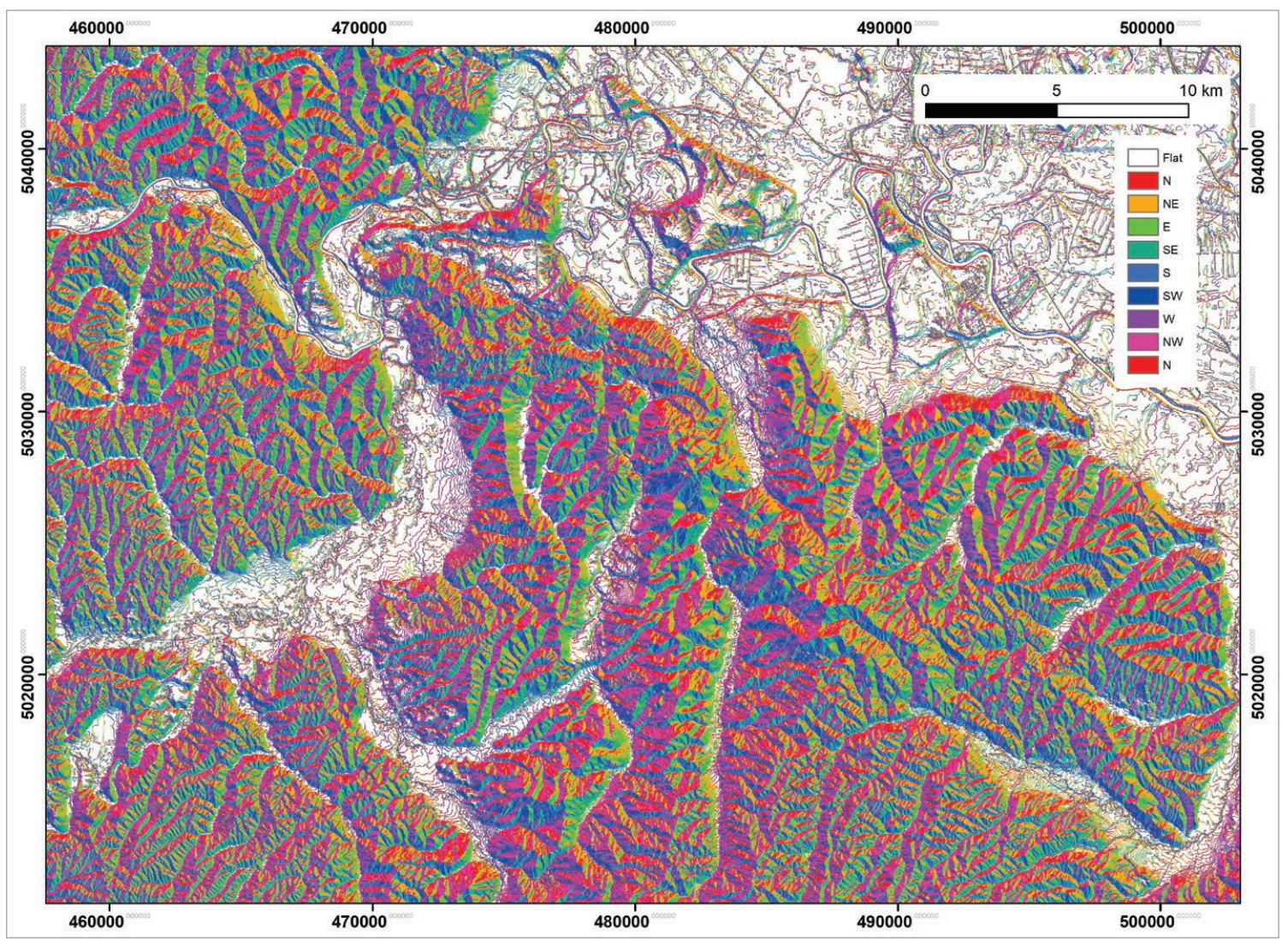

Fig. 5 Slope aspect of the Petrinja area

SI. 5. Karta ekspozicije padina okolice Petrinje 


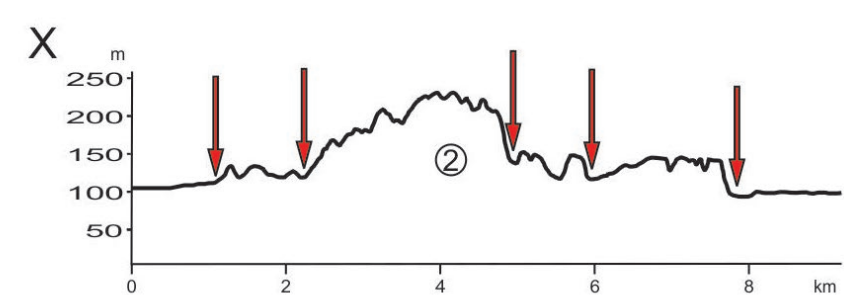

\section{Y}

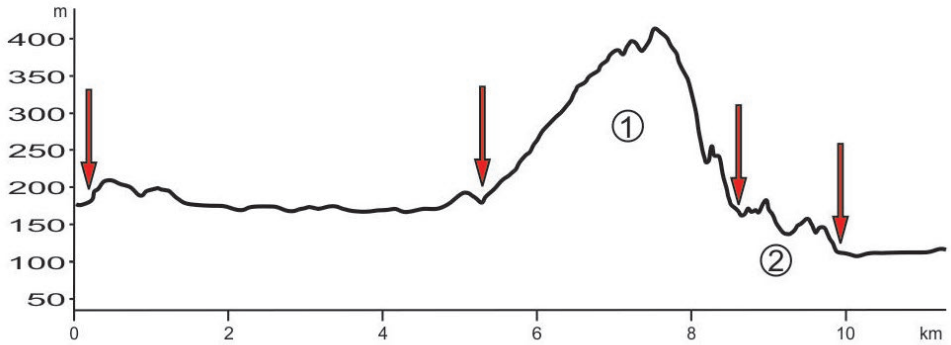

Fig. 6 Characteristic transversal topographic profiles of Hrastovicka Gora with the position of distinct morpholineaments and morphostructures 11 - the Hrastovica morphostructure, 2 - the Križ morphostructure, position of morpholineaments are marked with red arrows). For the profile position see Figure IB

SI. 6. Karakteristični poprečni topografski profili Hrastovičke gore s položajem izraženih morfolineamenata i morfostruktura (1 - mofostruktura Hrastovica, 2 - morfostruktura Križ, položaj morfolineamenata označen crvenim strelicama). Za položaj profila vidjeti sliku $1 \mathrm{~B}$

\section{Geomorphological indicators of active tectonics}

In addition to the analysis of the general morphometric characteristics of the studied area, an interpretation of the significant indicators of active tectonics was also carried out (Fig. 7). The main ridge of Hrastovička Gora extends in a generally northwest-southeast direction. In its southern part, the ridge is continuous for almost $10 \mathrm{~km}$ in the indicated direction. In the central part, the ridge has the same orientation, but is interrupted. In the northern part, the ridge is more interrupted and changes its orientation to WNW-ESE with sections that extend west-east. The secondary ridges generally have a meridional orientation, with minor deviations from this direction, which is diagonal in relation to the prevailing orientation of Hrastovička Gora. The secondary ridges are more sinuous, mainly due to erosion on the slopes. The position and orientation of long steep slopes may indicate the location of morpholineaments, and they may indirectly indicate possible traces of faults (so-called fault slopes). In this area, such slopes run $\mathrm{pa}^{-}$ rallel to the main ridges, mainly on the northeastern hillslope of Hrastovička Gora. Due to their steepness, these slopes are particularly exposed to erosion, which is visible in a series of parallel gullies.

\section{Geomorfološki indikatori aktivne tektonike}

Uz analizu općih morfometrijskih obilježja istraživanog područja izvršena je i interpretacija značajnijih indikatora aktivne tektonike (sl. 7). Glavni greben Hrastovička gore generalno se pruža pravcem sjeverozapad-jugoistok. U svom južnom dijelu greben je neprekinut u duljini od gotovo $10 \mathrm{~km}$, a pruža se navedenim pravcem. U središnjem dijelu greben je istog pružanja, ali postaje isprekidan. U sjevernom dijelu greben je više isprekidan te mijenja orijentaciju u ZSZ-IJI s dijelovima čije je pružanje zapad-istok. Sporedni grebeni su generalno meridionalne orijentacije, s manjim odstupanjima od tog smjera, što je dijagonalno u odnosu na glavni pravac pružanja Hrastovičke gore. Sporedni su grebeni zavojitiji, što je ponajprije posljedica erozije na padinama. Položaj i orijentacije dugačkih strmih padina mogu upućivati na pružanje morfolineamenata, a oni posredno na moguće tragove rasjeda (tzv. rasjedni strmci). Na ovom području takve padine pružaju se usporedo s glavnim grebeni$\mathrm{ma}, \mathrm{i}$ to ponajviše na sjeveroistočnom obronku. Zbog svoje strmine te su padine posebno izložene eroziji, što je vidljivo u nizu paralelnih jaruga. 
The most prominent relief forms in this area are watergaps. These sudden narrowings in part of the river/stream valley are often indicative of tectonic uplift (Burbank et al., 1999). Their beginnings and ends may indicate the location of active faults. No less than three streams flowing from south to north have carved water gaps through Hrastovička Gora. The southernmost is the water gap of the Petrinjcica Stream, $3.5 \mathrm{~km}$ long. In the first southern segment, which is $2.5 \mathrm{~km}$ long, the stream is oriented $25^{\circ}$, and in the second segment, which is $1 \mathrm{~km}$ long, it is oriented $80^{\circ}$. This is followed by the Utinja Stream water gap, which extends in the direction of $10^{\circ}$ and is also about $3.5 \mathrm{~km}$ long. These two water gaps intersect the main ridge of Hrastovicka Gora. After about $2.5 \mathrm{~km}$ of flow, Utinja has another short water gap (near Župić) that crosses the northern ridge of Hrastovička Gora (Župić Hills). The northernmost of all active water gaps is that of the Šanja Stream, which is about $2.5 \mathrm{~km}$ long. In the extreme northeast of Hrastovicka Gora there is another inactive water gap. Although there are two streams in it flowing to opposite sides, its formation is probably related to the breakthrough of a stronger stream in one direction. This was most likely the Utinja Paleostream, which once flowed into the Kupa River about $5 \mathrm{~km}$ upstream from its present mouth, but this should be investigated in more detail. This windgap, unlike other active ones, is different. It has a meandering shape, so it can be assumed that it is an incised meander, the appearance of which may indicate the slow uplift of the terrain.

Important geomorphological indicators include straight and narrow valleys and elbow-like valley bends. Although there are a large number of straight valley sections in the terrain, some of them have been singled out south of Hrastovička Gora, which mark possible morpholineaments well. Elbow-like turns of valleys may indicate the intersection of a valley with a fault line and may sometimes indicate a horizontal component of displacement along the fault. A large number of elbow-like turns have been recorded on this terrain, but the most significant at present are those associated with breakthroughs in Hrastovička Gora. All three active breakthroughs have double (left-right) on the inlet side and single (left) elbow turns of the valleys on the outlet side.
Najizraženiji reljefni oblik na ovom području jesu probojnice. To su nagla suženja u dijelu riječne doline, a često su mogući indikator tektonskog izdizanja (Burbank i dr., 1999). Njihovi počeci i završeci mogu ukazivati na položaj aktivnih rasjeda. Čak tri riječna toka koji s juga teku prema sjeveru usijecaju svoje probojnice kroz Hrastovičku goru. Najjužnija je probojnica Petrinjčice duljine $3,5 \mathrm{~km}$. Ona je u prvom, južnom dijelu, duljine $2,5 \mathrm{~km}$ orijentirana u smjeru $25^{\circ}$, a u drugom dijelu duljine $1 \mathrm{~km}$ orijentirana je u smjeru od oko $80^{\circ}$. Zatim slijedi probojnica Utinje koja se pruža prema $10^{\circ}$, također duljine oko $3,5 \mathrm{~km}$. Ove dvije probojnice presijecaju glavni greben Hrastovičke gore. Nakon oko 2,5 km toka Utinja ima još jednu kratku probojnicu (kod Župića) koja presijeca sjeverni greben Hrastovičke gore (Župić-brdo). Najsjevernija od svih aktivnih jest probojnica potoka Šanja duljine oko $2,5 \mathrm{~km}$. Na krajnjem sjeveroistoku Hrastovičke gore nalazi se još jedna, ali neaktivna probojnica. Iako se u njoj nalaze dva potoka koji otječu na suprotne stane, njezina geneza najvjerojatnije je povezana s probojem nekoga jačeg toka u jednom smjeru. Najvjerojatnije se radi o paleotoku Utinje koja se u Kupu ulijevala oko 5 km uzvodnije od današnjeg ušća, ali to tek treba detaljnije istražiti. Ova probojnica, za razliku od ostalih aktivnih, ima drukčiji tlocrt. Radi se o meandrirajućem obliku pa se opravdano može pretpostaviti da se radi o ukliještenim meandrima, čija pojava može ukazivati na postupno izdizanje terena.

Važan su geomorfološki indikator ravne i uske doline te laktasta skretanja dolina. Iako je na terenu prisutan veći broj ravnih dijelova dolina, u ovom radu izdvojeno ih je nekoliko južno od Hrastovičke gore, koje također ukazuju na potencijalne morfolineamente. Laktasta skretanja dolina mogu ukazivati na sjecište doline s rasjedom, a ponekad mogu i ukazati na horizontalnu komponentu pomaka po rasjedu. $\mathrm{Na}$ ovom terenu zabilježen je veći broj laktastih skretanja, ali kao trenutno najvažnija izdvojena su ona vezana za probojnice u Hrastovičkoj gori. Sve tri aktivne probojnice imaju na ulaznoj strani dvostruka (lijevo-desno), a na izlaznoj strani jednostruka
Structuralgeomorphological aspects of the

Petrinja earthquake

M6.2 (Croatia) - preliminary considerations

Strukturnogeomorfološki aspekti petrinjskog potresa M6.2 (Hrvatska) preliminarna razmatranja 
In addition, several such phenomena have been reported in the described breakthroughs. The most prominent example is the Šanja water gap, which forms a series of elbow turns. A series of double elbow turns of small parallel valleys in the northern part of Hrastovička Gora has also been recorded. A series of such elbow turns may also indicate the location of morpholineaments.

In the wider study area, several phenomena of river/stream piracy were observed, phenomena where one stream takes over a part to the catchment area of another stream. On the geomorphological map, two larger areas of stream piracy south of Hrastovička Gora and a smaller presumed zone of stream piracy at the confluence of Šanja and Utinja have been singled out. This phenomenon may have been caused by an increase in the hydraulic gradient of the drainage basin due to active tectonic movements. The stair-like forms in the relief prevail in the northern part of the terrain, and they are mostly the river terraces. Most of these stair-like forms are also distinct morpholineaments marking individual faults, most of which are known faults shown on the Basic Geological Map 1: 100000 sheet Sisak (Piki$\mathrm{ja}, 1987 \mathrm{a})$. The active tectonics of this area are also indicated by the fact that the terrain is predominantly composed of erodible younger deposits (Neogene and Quaternary deposits predominate) and the indicators of active tectonics are very well preserved.

\section{Discussion}

\section{Morpholineaments and morphostructures}

Morfolineaments are accentuated linear relief elements often associated with faults and fault zones. Therefore, they often serve as indicators that indicate the possibility of the existence of active faults. However, not all morpholineaments are also faults, so they cannot be interpreted with certainty without additional research. Morpholineaments can be marked with one or a series of geomorphological indicators. Within the framework of this paper, special attention was paid to the recognition of morpholineaments in the area of Hrastovička Gora, (lijeva) laktasta skretanja dolina. Uz to, nekoliko takvih pojava zabilježeno je i u opisanim probojnicama. Najizraženiji je primjer probojnica Šanje koja tvori niz laktastih skretanja. Također je zabilježena pojava niza duplih laktastih skretanja malih paralelnih dolina u sjevernom dijelu Hrastovičke gore. Niz takvih laktastih skretanja također može ukazivati na položaj morfolineamenta.

$\mathrm{Na}$ širem istraživanom prostoru uočeno je nekoliko pojava piraterija - gdje jedna tekućica preuzima dio slijeva druge tekućice. Na geomorfološkoj karti izdvojena su dva veća područja piraterije južno od Hrastovičke gore te jedna manja pretpostavljena zona piraterije na sutoku Šanje i Utinje. Tu pojavu može uzrokovati povećanje hidrauličkog gradijenta jednog slijeva uslijed aktivnih tektonskih pokreta. Pregibi u reljefu prevladavaju u sjevernom dijelu terena, a najčešće se radi o riječnim terasama. Većina ovih pregiba također su izraženi morfolineamenti koji markiraju pojedine, uglavnom već poznate rasjede prikazane na Osnovnoj geološkoj karti 1:100 000 list Sisak (Pikija, 1987a). Na aktivnu tektoniku ovog područja ukazuje i činjenica da je teren uglavnom izgrađen od erodibilnih mlađih naslaga (prevladavaju naslage neogena i kvartara), a indikatori aktivne tektonike jako su dobro očuvani.

\section{Rasprava}

\section{Morfolineamenti i morfostrukture}

Morfolineamenti su naglašeni linearni elementi reljefa često vezani za rasjede i rasjedne zone. Zbog toga često služe kao indikatori koji upućuju na mogućnost postojanja aktivnih rasjeda. Međutim, nisu svi morfolineamenti ujedno i rasjedi pa se bez dodatnih istraživanja ne mogu sa sigurnošću tako interpretirati. Morfolineamneti mogu biti markirani jednim ili nizom geomorfoloških indikatora. U okviru ovog rada na istraživanom je području posvećena osobita pažnja prepoznavanju i izdvajanju morfolineamenata u području Hrasto- 
i.e. in the zone of the Pokupsko Fault. Numerous morpholineaments were recognized in this zone, which may indicate certain branches or segments of this fault (Figs. 7 and 8).

In addition to the previously interpreted trace of the Pokupsko Fault at the northeastern foot of Hrastovička Gora (Korbar, 2021; Vukovski, 2021), in this paper we also interpret the morpholineaments on its southwestern side. Also, it seems that the morpholineament along the main line of the Pokupsko Fault in the northern part of Hrastovička Gora is slightly sigmoidally curved and possibly crosses over to its southwestern side, where it continues through part of the Kupa Valley and possibly further along the southwestern foot of Vukomeričke Gorice. (Fig. 7 segment N). If this interpretation is correct, it would mean that there is a transpressional ramp (restraining band) of this dextral fault in this segment, as is usually the case when there is a local change along horizontal faults corresponding to their strike (See also: Mann, 2007). A segment of the northeastern morfolineament continues to extend along the northeastern foot of Hrastovička Gora further towards Vukomeričke Gorice (Fig. 7 - segment S). North of this zone are several lineaments, most of which are already documented as established or assumed faults (Pikija, 1987a). South of this zone, several transverse and diagonal morpholineaments have been identified, although this area has not been analysed in detail so far in this work.

Morphostructures are specific geological structural units that have a clear reflection in relief, in other words they are mostly homogeneous relief forms of structural-tectonic origin (Gerasimov and Mescherikov, 1968). In previous literature describing the morphological features of this area, Hrastovička Gora was interpreted as a unique morphostructure (Hećimović and Prelogović, 1987). However, in this paper, a different interpretation is proposed, according to which two morphostructures might be present: (1) the Hrastovica morphostructure, further to the south and larger, with a NW-SE orientation; and (2) the Križ morphostructure, northerly and smaller, with a WNW-ESE orientation. If this assumption is correct, these two morphostructures would be separated by an east-west oriented morpholineament, possibly representing a segment of the vičke gore, tj. u zoni Pokupskog rasjeda. $U$ toj su zoni izdvojeni brojni morfolineamenti koji moguće ukazuju na pojedine ogranke ili segmente toga rasjeda (sl. 7 i 8),

Osim već ranije interpretirana traga Pokupskoga rasjeda uz sjeveroistočno podnožje Hrastovičke gore (Korbar, 2021; Vukovski, 2021), u ovom je radu interpretiran i morfolineament $s$ njegove jugozapadne strane. Također, čini se da je morfolineament po glavnom tragu Pokupskog rasjeda u sjevernom dijelu Hrastovičke gore blago sigmoidalno povijen te da moguće prelazi i na njezinu jugozapadnu stranu, gdje se po pružanju dalje nastavlja kroz dio doline Kupe pa moguće i dalje uz jugozapadno podnožje Vukomeričkih gorica (sl. 7 - segment S). Ukoliko bi ovakva interpretacija bila valjana, to bi značilo da je u tom dijelu transpresijska rampa toga desnog rasjeda, kako to i inače vrijedi u slučaju kada uz horizontalne rasjede dolazi do lokane promijene po njihovu pružanju (npr. Mann, 2007). Jedan segment sjeveroistočnog morfolineamenta nastavlja pružanje uz sjeveroistočno podnožje Hrastovičke gore dalje prema Vukomeričkim goricama (sl. 7 - segment N). Sjeverno od ove zone nalazi se nekoliko lineamenata od kojih su većina već poznati kao utvrđeni ili pretpostavljeni rasjedi (Pikija, 1987a). Južno od ove zone izdvojeno je nekoliko poprečnih i dijagonalnih morfolineamenata iako za sada to područje nije detaljnije analizirano u okviru ovog rada.

Morfostrukture su određene geološke strukturne jedinice koje imaju jasan odraz u reljefu ili, drukčije rečeno, to su uglavnom homogeni reljefni oblici strukturno-tektonskog postanka (Gerasimov i Mescherikov, 1968). U dosadašnjoj literaturi u kojoj se opisuju morfološke značajke ovog područja Hrastovička gora interpretirana je kao jedinstvena morfostruktura (Hećimović i Prelogović, 1987). Međutim, u ovom radu se predlaže drugačija interepretacija po kojoj su moguće dvije morfostrukture u ovom području: (1) morfostruktura Hrastovica, južnija i veća, s pružanjem SZ-JI te (2) morfostruktura Križ, sjevernija i manja, s pružanjem ZSZ-IJI. Ako je ovakva pretpostavka točna, te bi dvije morfostrukture bile odijeljene morfolineamentom pružanja istok-zapad, koji moguće predstavlja jedan segment Pokupskoga
Structuralgeomorphological aspects of the

Petrinja earthquake

M6.2 (Croatia) - preliminary considerations

Strukturnogeomorfološki aspekti petrinjskog potresa M6.2 (Hrvatska) preliminarna razmatranja 
HRVATSKI

GEOGRAFSKI

GLASNIK

$83 / 1,5-24(2021$.

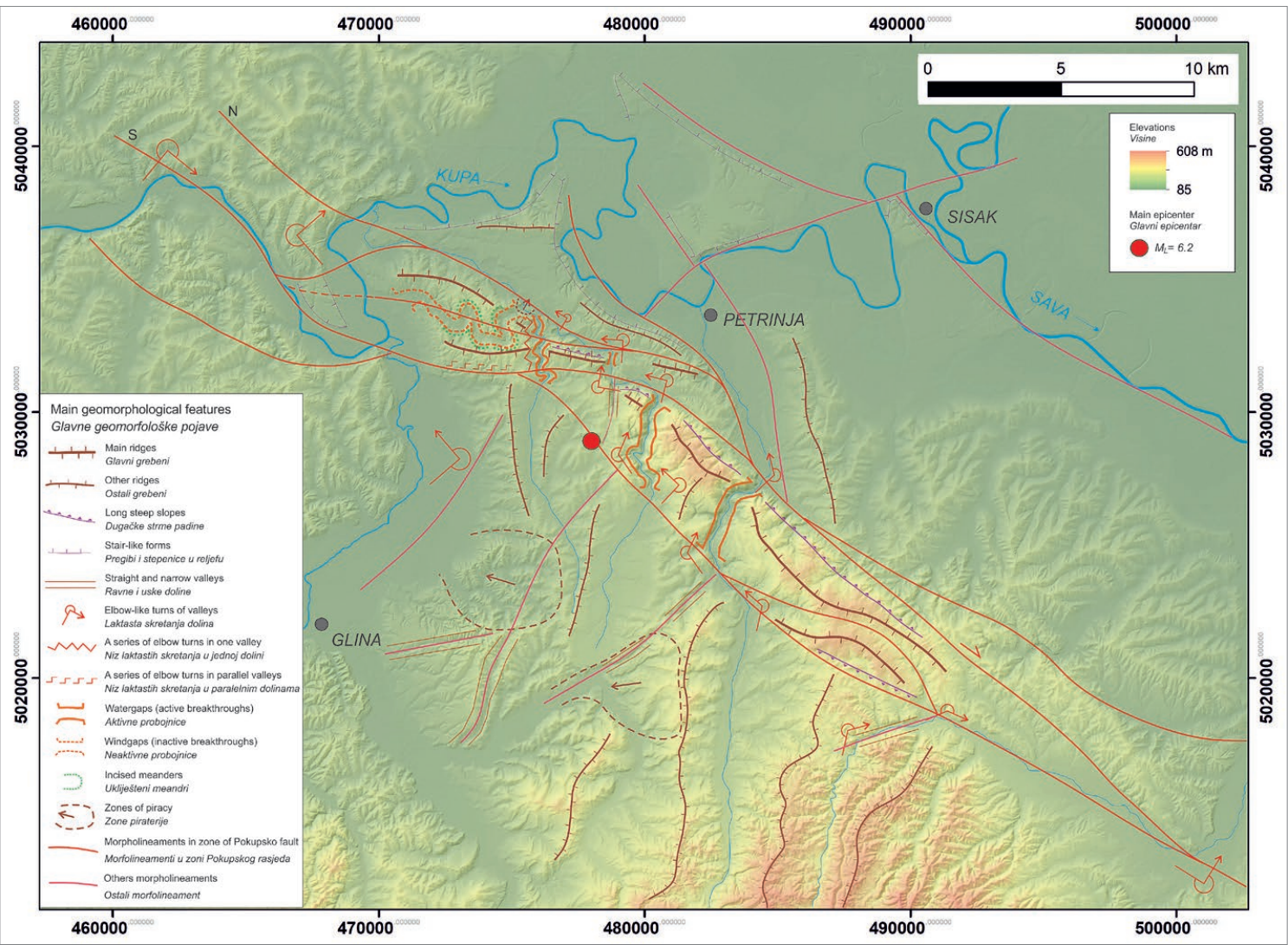

Fig. 7 Preliminary structural-geomorphological map of the area in the epicentre zone of the Petrinja earthquake 2020/2021. N and S denote the northern and southern segments of the described morpholineament

SI. 7. Preliminarna strukturno-geomorfološka karta područja u zoni epicentra glavnog potresa petriniske serije 2020. - 2021. N i s označavaju sjeverni i južni segment opisanog morfolineamenta

Pokupsko Fault. Its location and the characteristics of the defined morphostructures indicate that this segment may be a transpressional ramp (restraining band) of the Pokupsko Fault along which a local positive-flower or pop-up structure may have formed, as described in literature regarding horizontal displacement faults (See: Sylvester, 1988; McClay and Bonora, 2001; Legg et al., 2007).

\section{Structural-geomorphological features and epicentres of earthquakes}

The presented structural-geomorphological data were compared with the spatial distribution of the strongest epicentres of the recent earthquakes of the Petrinja series $\left(M_{L}>=4\right.$, of which 15 were recorded in the period from December $28^{\text {th }}, 2020$ to March $\left.3^{\text {rd }}, 2021\right)$ (Fig. 8). Preliminary findings sug- rasjeda. Ovakav položaj toga segmenta i značajke izdvojenih morfostruktura ukazuju da je navedeni segment moguće transpresijska rampa Pokupskoga rasjeda duž kojeg je moguće nastala lokalna pozitivna cvjetna, odnosno pop-up struktura, kako je to i opisano u literaturi o rasjedima s pomakom po pružanju (npr. Sylvester, 1988; McClay i Bonora, 2001; Legg i dr., 2007).

\section{Strukturno-geomorfološka obiliežja i epicentri potresa}

Prezentirani strukturno-geomorfološki podaci uspoređeni su s prostornim rasporedom epicentara nedavnih potresa petrinjske serije (sl. 8). Preliminarnim uvidom nameću se dva zaključka. (1) Veći broj epicentara jakih potresa nalazi se na jugozapadnoj strani Hrastovičke gore, bliže 


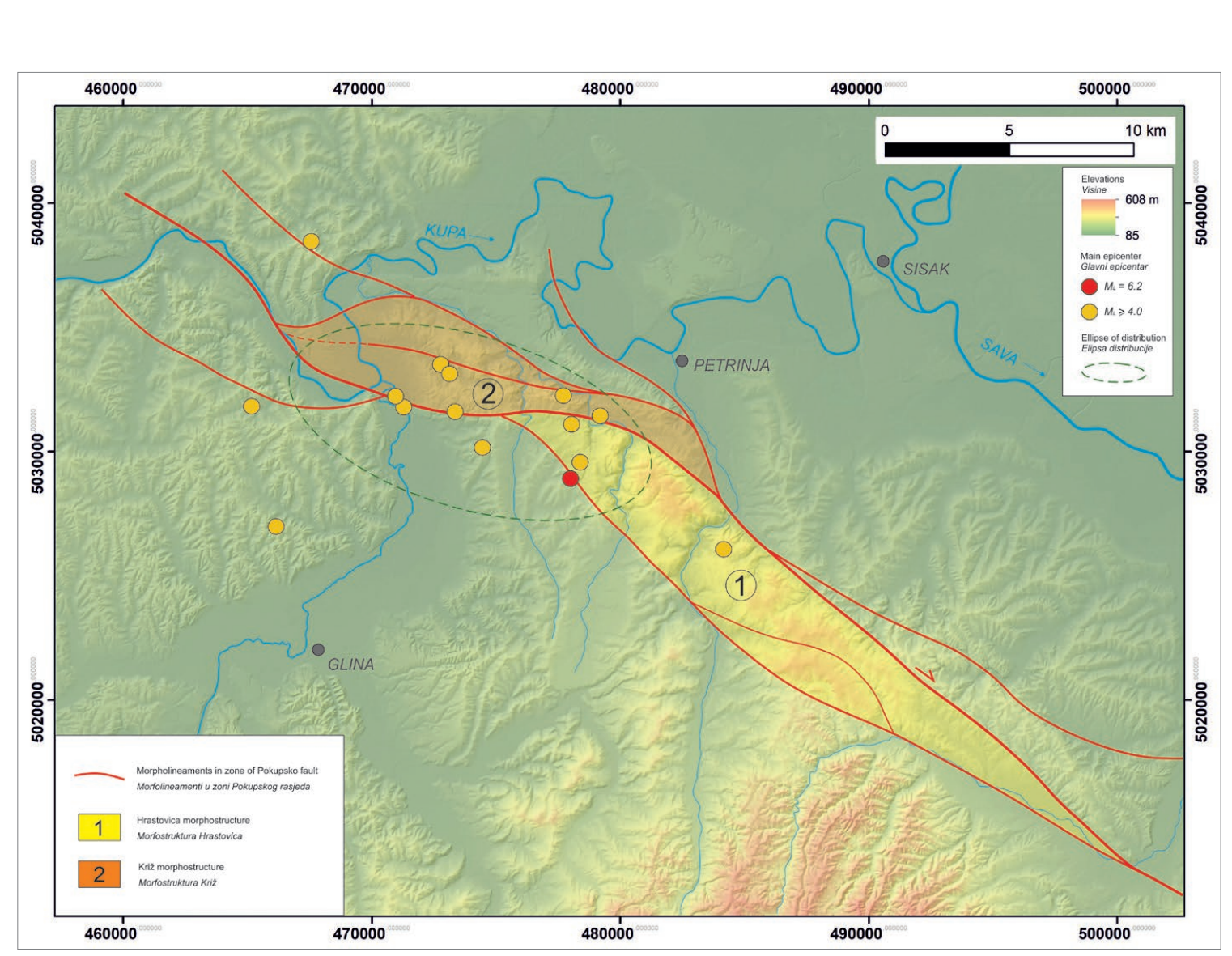

Fig. 8 Preliminary map of morpholineaments and morphostructures of the area in the epicentre zone of the 2020/2021 Petrinja earthquake(s). The locations of epicentres are approximate, plotted according to data from Seismological Survey, 2021b

SI. 8. Preliminarna karta morfolineamenata i morfostruktura područja u zoni epicentara petriniskog potresa 2020. - 2021. Lokacije epicentara su okvirne, ucrtane prema podacima iz Seizmološke službe (2021b)

gest two conclusions. (1) A large number of strong earthquake epicentres were located on the southwestern side of Hrastovička Gora, closer to the morpholineament, which may be a southwestern branch of the Pokupsko Fault. However, if further research shows that it is an active fault, this does not necessarily mean that the earthquake hypocentres are caused by it, since the fault plane may also be curved at depth and therefore its position at depth does not necessarily correspond to a line of a marked morpholineament at the surface. (2) The epicentres of the strongest earthquakes are concentrated near the contact point of the two separate morphostructures which are separated by a morpholineament running from the northeastern to the southwestern side of Hrastovička Gora. The spatial distribution of the epicentre is represented by the distribution ellipse (Fig. 8). morfolineamentu koji potencijalno predstavlja jugozapadni ogranak Pokupskog rasjeda. No, ako se i daljnjim istraživanjima pokaže da se radi o aktivnom rasjedu, to nužno ne znači da su žarišta potresa uzrokovana tim rasjedom jer rasjedna ploha u dubini može također biti povijena, pa stoga i njezin položaj u dubini ne mora nužno odgovarati tragu izdvojenog morfolineamenta na površini. (2) Epicentri najjačih potresa $\left(M_{L}\right.$ $>=4$, kojih je u razdoblju od 28.12. 2020. do 3 . 3. 2021. zabilježeno 15) koncentrirani su blizu kontakta navedenih dviju interpretiranih odvojenih morfostruktura, a koje su odvojene morfolineamentom koji prelazi sa sjeveroistočne na jugozapadnu stranu Hrastovičke gore. Prostorni raspored epicentara prikazan je elipsom distribucije (sl. 8).
Structuralgeomorphological aspects of the Petrinja earthquake

M6.2 (Croatia) - preliminary considerations

Strukturnogeomorfološki aspekti petrinjskog potresa M6.2 (Hrvatska) preliminarna razmatranja 
Although more data would be needed for more certain conclusions, preliminary results indicate the orientation of the ellipse in the direction $107-287^{\circ}$, which is rotated about $25-30^{\circ}$ counter clockwise with respect to the prevailing Dinaric orientation, i.e. the strike of the fault line along the northeastern foothills of Hrastovička Gora. If we add to this the rather high numerical eccentricity of the ellipse of 0.89 , which indicates an elongated distribution of epicentres, we can tentatively conclude that there is a spatial relationship between the strike of this morpholineament and the epicentres of earthquakes in the vicinity. According to current knowledge, the Pokupsko Fault Zone's right displacement is a consequence of recently active tectonic stress on the main $\mathrm{N}-\mathrm{S}$, i.e. NNE-SSW, compressional axis (Bada et al., 2007; Herek and Herak, 2010).

Due to the stress regime, this segment of the Pokupsko Fault would be its transpressional ramp. Similarly, Barka and Kadinsky-Cadestrike (1988), while analysing horizontal displacement faults in Turkey, found that the strongest earthquakes in Turkey related to horizontal faults occurred along segments of faults that exhibited compression or double bending, and they attributed this to the accumulation of tension in these zones. The possibility of similar such phenomena is also mentioned, for example, by King and Nabelek (1985), Butler et al. (1998), Yule and Sieh (2003), Mann (2007), and Legg et al. (2007). On the other hand, based on studies along San Andreas Fault Zone, Graymer et al. (2007) stated that the surface complexity of the fault zone is often lost with depth, so that at depths greater than $5 \mathrm{~km}$, seismogenic faults are often of simple geometry. Therefore, to confirm the hypothesis presented here, further geophysical, geological and geomorphological studies of this seismic area are required.

\section{Conclusion}

This research has shown that there are numerous traces and indications of active tectonics in the relief of the area affected by the main earthquake of magnitude 6.2 of the 2020/2021 Petrinja series. Based on their spatial distribution, morpholineaments were reconstructed that correspond, at least in part, to lines of active faults in the Pokupsko Fault Zone. It is
Iako bi za sigurnije zaključke trebalo više podataka, preliminarni rezultati ukazuju na orijentaciju elipse pravcem $107-287^{\circ}$, što je za oko $25-30^{\circ}$ obrnuto od kazaljke na satu zaokrenuto u odnosu na dinarsku orijentaciju, tj. na pružanje trase rasjeda uz sjeveroistočno podnožje Hrastovičke gore. Ako tome dodamo i prilično visok numerički ekscentricitet elipse od 0,89, koji ukazuje na izduženu distribuciju epicentara, možemo preliminarno zaključiti da postoji određena prostorna veza između pružanja ovog morfolineamenta i pojave epicentara potresa. Prema dosadašnjim saznanjima zona Pokupskog rasjeda s desnim pomakom posljedica je recentno aktivnog tektonskog naprezanja glavnom kompresijskom osi pružanja S-J, odnosno NNESSW (Bada i dr., 2007; Herek i Herak, 2010).

U ovakvom režimu naprezanja taj bi segment Pokupskoga rasjeda bila njegova transpresijska rampa. Slično su u analizi rasjeda s horizontalnim pomakom u Turskoj utvrdili Barka i Kadinsky-Cadestrike (1988) koji smatraju da se većina jakih potresa u Turskoj, koji su vezani za horizontalne rasjede, pojavljuje duž onih segmenata rasjeda koji imaju kompresijsko ili dvostruko svijanje, a to pripisuju nakupljanju napetosti u tim zonama. Također, mogućnosti sličnih takvih pojava navode npr. Kinga i Nabeleka (1985), Butler i dr. (1998), Yule i Sieh (2003), Mann (2007) te Legg i dr. (2007). Međutim, Graymer i dr. (2007), na temelju istraživanja duž rasjedne zone San Andreas, upozoravaju na to da se površinska kompleksnost seizmogene rasjedne zone često gubi s dubinom, gdje su na dubinama većim od $5 \mathrm{~km}$ seizmogeni rasjedi često jednostavne geometrije. Stoga, da bi se ovdje predstavljena hipoteza potvrdila, potrebna su dodatna geofizička, geološka i geomorfološka istraživanja ovoga potresnoga područja.

\section{Zaključak}

Ovo istraživanje pokazalo je da postoje brojni tragovi i indikatori aktivne tektonike $\mathrm{u}$ reljefu područja koje je pogodio glavni potres magnitude 6.2 petrinjske serije. $\mathrm{Na}$ temelju njihova prostornog rasporeda rekonstruirani su morfolineamenti koji barem dijelom moguće odgovaraju tragovima aktivnih rasjeda u Pokupskoj rasjednoj zoni. Pret- 
assumed that the interpreted morpholineaments and morphostructures are due to horizontal and vertical tectonic movements within this fault zone. In this work, Hrastovička Gora is interpreted as a positive flower or pop-up structure that consists of at least two morphostructures. A concentration of the epicentres of the strongest earthquakes was observed in the morpholineament zone, which may represent a fault segment of the Pokupsko Fault Zone, i.e. its transpressional ramp (restraining band). Further detailed geophysical, geological and geomorphological studies are required to confirm this hypothesis.

The author would especially like to thank Bruno Tomljenović, Josip Stipčević and Tamás Telbisz for their valuable suggestions in the preparation of this article. postavlja se da su interpretirani morfolineamenti i morfostrukture posljedica horizontalnih i vertikalnih tektonskih pokreta unutar ove rasjedne zone. U ovom radu je Hrastovička gora interpretirana kao pozitivna crjetna ili pop-up struktura, a sastoji se od najmanje dvije morfostrukture. Uočena je koncentracija epicentara najjačih potresa u zoni morfolinementa koji potencijalno predstavlja segment rasjeda Pokupske rasjedne zone odnosno njegovu transpresijsku rampu. Za potvrdu ove hipoteze potrebna su daljnja detaljna geofizička, geološka i geomorfološka istraživanja.

$\mathrm{Na}$ vrijednim sugestijama prilikom izrade ovog članka autor posebno zahvaljuje Bruni Tomljenoviću, Josipu Stipčeviću i Tamásu Telbiszu.
Aslam, B., Naseer, F. A., 2020: Statistical analysis of the spatial existence of earthquakes in Balochistan: clusters of seismicity, Environmental Earth Sciences 79, 41, https://doi.org/10.1007/s12665019-8790-2.

Bada, G., Horvath, F., Dövényi, P., Szafián, P., Windhoffer, G., Cloetingh, S., 2007: Present-day stress field and tectonic inversion in the Pannonian basin, Global and Planetary Change 58, 165180, https://doi.org/10.1016/j.gloplacha.2007.01.007.

Barka, A.A., Kadinsky-Cadestrike, K., 1988: Slip fault geometry in Turkey and its influence on earthquake activity, $T e$ ctonics 7 (3), 663-684.

Bočić, N., 2021: Neki geomorfološki aspekti Petrinjskog potresa, Geografija. hr, https://geografija.hr/clanci/neki-geomorfoloski-aspekti-petrinjskog-potre$\mathrm{sa} /(16.1 .2021$.$) .$

Bognar, A., 1999: Geomorfološka regionalizacija Hrvatske, Acta Geographica Croatica 34, 7-29.

Burbank, D. W., McLean, J. K., Bullen, M., Abdrakhmatov, K. Y., Miller, M. M., 1999: Partioning of intermontane basin by thrust-related folding, Tien Shan, Kyrgyzstan, Basin Research 11, 75-92, doi.org/10.1046/j.13652117.1999.00086.x.

Butler, R. W. H., Spencer, S., Griffiths, H. M., 1998: The structural response to evolving plate kinematics during transpression: evolution of the Lebanese restraining bend of the Dead Sea Transform, Geological Society, London,
Special Publications 135 (1), 81-106, doi: 10.1144/gsl.sp.1998.135.01.06.

Djenaliev, A., Kada, M., Chymyrov, A., Hellwich, O., Muraliev, A., 2018: Spatial Statistical Analysis of Earthquakes in Kyrgyzstan, International Journal of Geoinformatics 14 (1), 11-20.

Dogom, D., Schuckma, K., Al Ruzouq, R., 2018: Geostatistical seismic analysis and hazard assessment; United Arab Emirates, The International Archives of the Photogrammetry, Remote Sensing and Spatial Information Sciences XLII-3/W4, 29-36, https://doi.org/10.5194/isprs-archives-XLII-3-W4-29-2018.

Đapo, A., Pavasović, M., Pribičević, B., Prelogović, E., 2020: Combined Space-Time Analysis of Geodetic and Geological Surveys for Evaluation of the Reliability of the Position of Points in the Geodynamic Network of the City of Zagreb, Geosciences 10, 498, doi:10.3390/ geosciences 10120498.

Gerasimov, I. P., Mescherikov, J. A., 1968: Morphostructure, In: Geomorphology. Encyclopedia of Earth Science, Springer, Berlin, Heidelberg, 731-732.

Graymer, R. W., Langenheim, V. E., Simpson, R. W., 2007: Relatively simple through-going fault planes at large-earthquake depth may be concealed by the surface complexity of strike-slip faults, in: Cunningham, W. D., Mann, P. (eds.): Tectonics of Strike-Slip Restraining and Releasing Bends, Geological Society, London, Special Publications 290, 189201, DOI: 10.1144/SP290.5.

Hećimović, I., Prelogović, E., 1987: Geo- morfološka analiza, u: Pikija, M. (ur.): Tumač osnorne geološke karte 1:100.000, list Sisak, Hrvatski geološki institut $\mathrm{Za}-$ greb, Savezni geološki zavod, Beograd, 31-35.

Herak, M., 1991: Dinaridi, mobilistički osvrt na genezu i strukturu, Acta Geologica 21 (2), 35-117.

Herak, D., Herak, M., Tomljenović, B., 2009: Seismicity and earthquake focal mechanisms in North-Western Croatia, Tectonophysics 465, 212-220.

Herak, D., Herak, M., 2010: The Kupa Valley (Croatia) Earthquake of 8 October 1909-100 Years Later, Seismological Research Letters 81, 30-36.

King, G. C. P., Nabelek, J., 1985: Role of fault bends in the initiation and termination of earthquake rupture, Science 228, 984-987.

Korbar, T., 2021: Priopćenje za medije Izvješće Hrvatskog geološkog instituta o potresima, https://www.hgi-cgs.hr/ priopcenje-za-medije-izvjesce-hrvatskog-geoloskog-instituta-o-potresima/ (10.1. 2021.).

Lapaine, M., Tutić, D., 2007: O novoj službenoj kartografskoj projekciji Hrvatske - HTRS96/TM, Kartografija i geoinformacije 6 (izv./spec.), 34-53.

Legg, M. R., Goldfinger, C., Kamerling, M. J., Chaytor, J. D., Einstein, D. E., 2007: Morphology, structure and evolution of California Continental Borderland restraining bends, in: Cunningham, W. D., Mann, P. (eds.): Tectonics of Strike-Slip Restraining and Releasing Bends, Geological Society, London, Special Pu-

\section{Acknowledgement}

Zahvala

Literature

Literatura 
GEOGRAFSKI

GLASNIK

83/1, 5-24 (2021.)

Sources

Izvori

Author

Autor blications 290, 143-168, DOI: 10.1144/ SP290.3.

Mann, P., 2007: Global catalogue, classification and tectonic origins of restraining- and releasing bends on active and ancient strike-slip fault systems, in: $\mathrm{Cu}$ nningham, W. D., Mann, P. (eds.): Tectonics of Strike-Slip Restraining and Releasing Bends, Geological Society, London, Special Publications 290, 13-142, doi: 10.1144/SP290.2.

Markušić, S., Herek, M., 1998: Seismic Zoning of Croatia, Natural Hazards 18 , 269-285.

Markušić, S., Stanko, D., Penava, D., Ivančić, I., Bjelotomić Oršulić, O., Korbar, T., Sarhosis, V., 2021: Destructive M6.2 Petrinja Earthquake (Croatia) in 2020Preliminary Multidisciplinary Research, Remote Sensing 13, 1095, https://doi. org/10.3390/rs13061095.

McClay, K., Bonora, M., 2001: Analog models of restraining stepovers in strike-slip fault systems, AAPG Bulletin 85 (2), 233-260

Mihalić Arbanas, S., Arbanas, Ž., Krkač, K., Bernat Gazibara, B., Damjanović, V., Sinčić, M., Jagodnik, P., Jagodnik, V., 2021: Potres u Petrinji M6,2 od 29.12.2020: izvješće o inženjerskogeološkoj i geotehničkoj prospekciji, Rudarsko-geološko-naftni fakultet, https://www.rgn. unizg.hr/images/izdvojeno/UNIZR-RGNF_UNIRI-GF_potes_Petrinja_ M6.2_ig_i_gt_prospekcija.pdf (12. 2 . 2021.).

Pikija, M., 1987a: Osnovna geološka karta 1:100 000, list Sisak L33-93, Hrvatski geološki institut Zagreb, Savezni geološki zavod, Beograd.

Pikija, M., 1987b: Osnovna geološka karta 1:100 000, Tumač za list Sisak L33-93, Hrvatski geološki institut Zagreb, Savezni geološki zavod, Beograd, 51 str.

Prelogović, E., Saftić, B., Kuk, V., Velić, J., Dragaš, M., Lučić, D., 1998: Tectonic activity in the Croatian part of the Pannonian basin, Tectonophysics 297, 283-293.

Sylvester, A. G., 1988: Strike-slip faults, Geological Society of America Bulletin 100, 1666-1703

Šikić, K., 1990: Osnovna geološka karta 1:100 000, list Bosanski Novi, Hrvatski geološki institut, Zagreb.

Šikić, K., 2014: Tumač osnovna geološka karta 1:100 000, list Bosanski Novi, Hrvatsk geološki institut Zagreb, 82 str.

Terzić, J., Frangen, T., Kosović, I., 2021: Urušavanje tla u Mečenčanima i okolici izazvano potresom magnitude 6.2 kod Petrinje, te prethodnim i naknadnim potresima - Izvješće s podatcima do kraja siječnja, 2021, Hrvatski geološki institut, https://www. hgi-cgs.hr/urusavanje-tla-u-mecencanima-i-okolici-izazvano-potresom-magnitude-6-2-kod-petrinje-te-prethodnim-i-naknadnim-potresima/(10. 1 2021.).

Tomljenović, B., Stipčević, J., Sečanj, M. 2021: Izvješće o zabilježenim pojavama koseizmičkih površinskih deformacija na području Pokuplja i Banovine nastalih potresnom serijom od 28.12. 2020 do 5.01.2021., https://www.rgn.unizg. hr/hr/izdvojeno/2790-izvjesce-o-zabiljezenim-pojavama-koseizmickih-povrsinskih-deformacija-na-podrucju-pokuplja-i-banovine-nastalih-potresnom-serijom-od-28-12-2020-do5-01-2021 ? fbclid=IwAR1eZvDEdOvS_gSK81uk5ASpcoRrih6LoNtTyZsnG3m5Jlnuop9uXLiaQuE Rudarsko-geološko-naftni fakultet (10.1.2021.).

Tondi, E., Blumetti, A. M., Čičak, M. Di Manna, P., Galli, P., Invernizzi, C., Mazzoli, S., Piccardi, L., Valentini, G., Vittori, E., Volatili, T., 2021: 'Conjugate' coseismic surface faulting related with the 29 December 2020, Mw 6.4, Petrinja earthquake (Sisak-Moslavina, Croatia), Scientific Reports 11, 9150, https:// doi.org/10.1038/s41598-021-88378-2.

Ustaszewski, K., Herak, M., Tomljenović, B., Herak, D., Matej, S., 2014: Neotectonics of the Dinarides-Pannonian Basin transition and possible earthquake sources in the Banja Luka epicentral area, Journal of Geodynamics 82, 52-68.

Vukovski, M., 2021: Potres u Petrinji - preliminarno izvješće, Hrvatski geološki institut, https://www.hgi-cgs. $\mathrm{hr} /$ potres-u-petrinji-preliminarno-izvjesce/?fbclid=IwAR1NAXVXMrjwvN4Q1DAZywOygI9hRrXc12154rz4axQMClTdMnlpfiQCtPs (10. 1 . 2021.).

Yule, D., Sieh, K., 2003: Complexities of the San Andreas fault near San Gorgonio Pass: Implications for large earthquakes, Journal of Geophysical Research 108 (B11), 2548.

ArcGIS, 2021: Directional Distribution (Standard Deviational Ellipse), https://desktop.arcgis.com/en/arcmap/10.3/tools/spatial-statistics-toolbox/directional-distribution.htm (23.5.2021.).

Croatian Geodetic Administry/Državna geodetska uprava, 2021: Geoportal, https://geoportal.dgu.hr/ (25.3.2021.).

Faculty of Geodesy/Geodetski fakultet, 2020: Karta površinskih pomaka dobivena satelitskom radarskom interferometrijom za Petrinjski potres magnitude 6.3, https://www.geof.unizg.hr/novosti/karta-povrsinskih-pomaka-dobivena-satelitskom-radarskom-interferometrijom-za-petrinjski-potres-magnitude-6-3/ (25.3.2021.).

Seismological Survey/Seizmološka služba, 2021a: Izvješća o potresima, https://www.pmf.unizg.hr/geof/seizmoloska_sluzba/izvjesca_o_potresima (30.3.2021.).

Seismological Survey/Seizmološka služba, 2021b: Izvješća o potresima: arhiva obavijesti, https://www.pmf.unizg.hr/geof/seizmoloska_ sluzba/izvjesca_o_potresima?@=1itab\#news_45225 (19.5.2021.).

Seismological Survey/Seizmološka služba, 2021c: Preliminarni rezultati serije potresa kod petrinje od 28. prosinca 2020. do 28. siječnja 2021., https://www.pmf.unizg.hr/geof/seizmoloska_sluzba/mjesec_dana_od_glavnog_petrinjskog_potresa (25.3.2021.).

Share, 2021: The European Database of Seismogenic Faults, http://diss.rm.ingv.it/share-edsf/sharedata/SHARE_WP3.2_Map.html (25.3.2021.)

Neven Bočić nbocic@geog.pmf.hr PhD, Associate Professor, University of Zagreb, Faculty of Science, Department of Geography, Marulićev trg 19/II, 10000 Zagreb, Croatia 